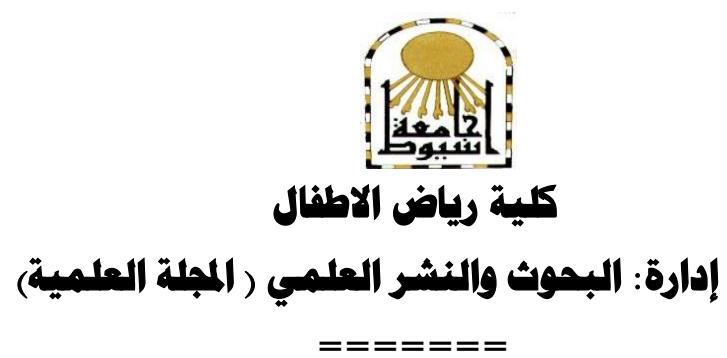

\title{
إستراتيجية مقترحة لتوظيف بنك المعرفة فى الأنشطة العلمية لطفل الروضة
}

\author{
إعــــد
}

أ. سماه عبد|الفتاه هممد همزفة

$$
\text { مدرس بقسم العلوم التربوية }
$$

كلية التربية للطقولة المبكرة- جامعة القاهرة

$$
\{\text { العدد السابع- أكتوير 1 1 + r }\}
$$




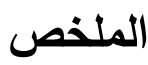

هدفت الدراسة الى أعداد إستراتيجية مقترحة لتوظيف بنك المعرفة فى الأنشطة العلمية لطفل الروضة، وتكونت عينة البحث من (T) 1 ( ) معلمة متخصصة برياض الأطفال بمحافظتى (القاهرة والجيزة)، تضمنت عدد حوالى(V乏 معلمة) بمحافظة القاهرة و(Y) معلمة) بمحافظة الجيزة، وقد تم تحديد مشكلة البحث فى التساؤلات التالية ما الجوانب المعرفية التى تحتاجها المعلمات لتوظيف بنك المعرفة فى الأنشطة العلمية؟، ما الجوانب المهارية التى تحتاجها المعلمات لتوظيف بنك المعرفة فى الأنشطة العلمية ؟، وما الإستراتيجية المقترحة لتوظيف بنك المعرفة فى الأنشطة العلمية برياض الأطفال ؟، وأتبع البحث المنهج الوصفى التحليلى، وللأجابة على تساؤلات البحث قامت الباحثة بأعداد أستبيان لقياس الوعى (بينك المعرفة المصرى) لدى معلمات رياض الأطفال، وقد أظهرت نتائج البحث الى وجود نسبة انخفاض في مستوى وعي المعلمات بإستخدام بنك المعرفة في الانشطة العلمية، وقد يمكن إرجاع هذه النتيجة إلى قصور ناتج عن عدم إلمام معلمات رياض الأطفال بالجوانب التكنولوجية الحديثة وكيفية توظيفها، إلى جانب عدم وضوح بعض هلئه المعلومات عن بنك المعرفة وكيفية توظيفة لتنمية بعض المفاهيم العلمية، ومن خلال ذلك تم طرح إستراتيجية مقترحة لتوظيف بنك المعرفة فى الأنثطة العلمية لدى معلمات رياض هي الأطفال كحل أساسي لتطوبر المستوي التعليمي ليواكب التطور الحالي في المراحل التعليمية المختلفة والعمل علي تحديد وجهة الجيل القادم نحو مجتمع ناجح فعال.

الكلمات المفتاحية: إستراتيجية، بنك المعرفة، الأنشطة العلمية، طفل الروضة. 


\title{
A Proposed Strategy for the Employment of the Knowledge Bank in the Scientific Activities of Kindergarten Child
}

\begin{abstract}
:
The study aimed at developing a proposed strategy for employing the knowledge bank in the scientific activities of the Kindergarten child. The sample consisted of 116 specialized kindergarten teachers in the governorates of Cairo and Giza. They included 74 teachers in Cairo governorate and 42 teachers in Giza governorate. The research problem was developed according to the following questions: What are the cognitive aspects that teachers need to employ the knowledge bank in scientific activities? What are the technical aspects that teachers need to employ the knowledge bank in scientific activities? In addition, the researcher has prepared a questionnaire to assess the knowledge of the Egyptian Knowledge Bank among kindergarten teachers. The results of the research showed that teachers' awareness level of the use of the knowledge bank in scientific activities was low. This result may be attributed to the lack of knowledge of the kindergarten teachers about the modern technological aspects and how to employ them, as well as the lack of clarity of some information about the knowledge bank and how to make use of it to develop some scientific concepts. In addition, a proposed strategy has been put forward to employ the Knowledge Bank in the scientific activities of kindergarten teachers as a basic solution for the development of the educational level to cope with the current development in different educational stages and to direct the next generation towards a successful and effective society.
\end{abstract}

Keywords: Strategy, Knowledge Bank, Scientific Activities, Kindergarten Child. 


\section{مقدمة}

يشهد هذا العصر تطورات مستمرة في الوسائط التكنولوجية التي يمكن إستخدامها

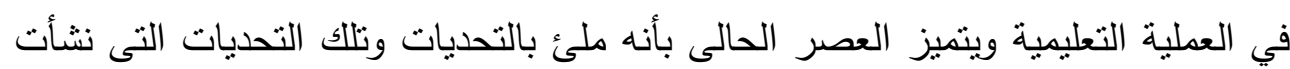
للتصدى لعصر العولمة والآثار التى يمكن أن تحدثها فى الكبار والصغار ، والتتافس والتقام الكبير الذي حققته بعض الدول فيما يسمى بثورة الإتصالات وعالم التكنولوجيا، والانفجار

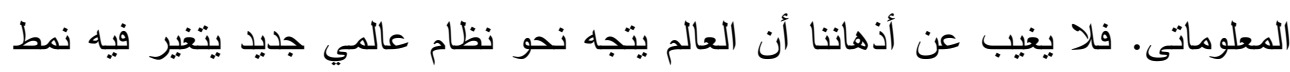

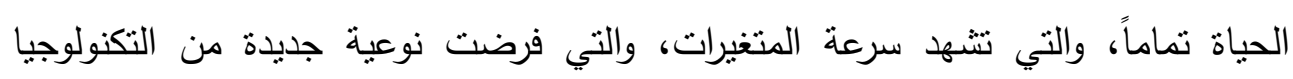

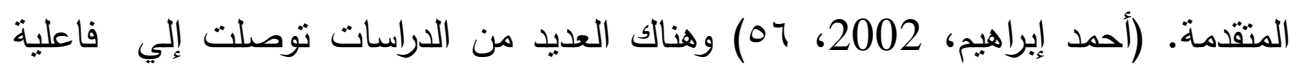

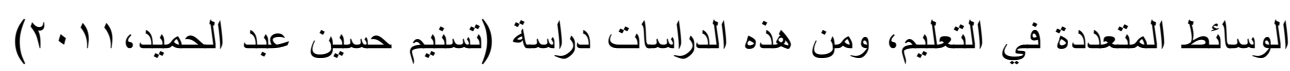

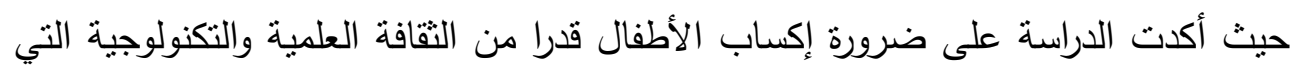
تمكنهم من إستيعاب ما يحدث من تقدم علمي وتكنولوجي من خلال الوسائط المتعددة

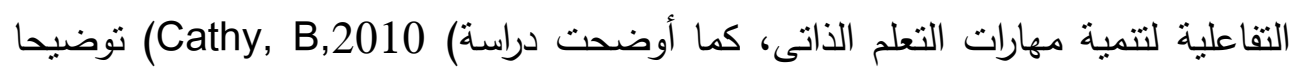
للمجالات والمفاهيم التي يجب نتميتها في هذه المرحلة من الثقافة الرقمية والإليكترونية في دراستها عن التكنولوجيا والتقافة في الطفولة المبكرة وحتى ^ سنوات منها معرفة وتطبيق المفاهيم والمبادئ وعمليات الأستقصاء والموضوعات العلمية ومعرفة المفاهيم الأساسية والمبادئ التي تربطنا بالحياة علوم الأرض والفضاء وتطبيق المفاهيم العلمية القابلة للممارسة الهية التي تصف العلاقة بين العلوم والتكنولوجيا والمجتمع. وأيضا نجد أن الكثير من الدراسات توصلت إلي فاعلية البرامج التعليمية التي تقدم

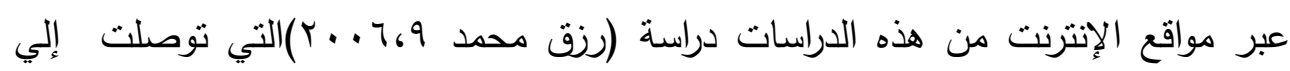
فاعلية الموقع التعليمي الذي قام بتصميمه في إكساب المتعلمين عينة البحث المهارات

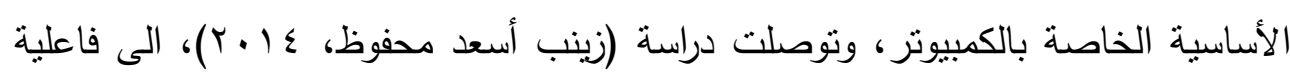
إستخدام الوسائط المتعددة في تتمية بعض مفاهيم النقافة السياحية التاريخية الفرعونية التي وني

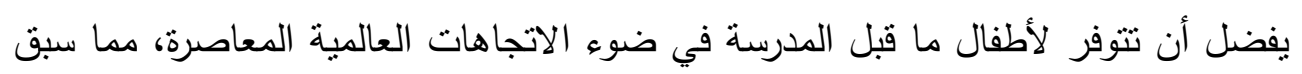
يتضح أن هناك اهتماما متزايدا نحو التوسع في استخدام أسلوب التعلم عن بعد في التعليم

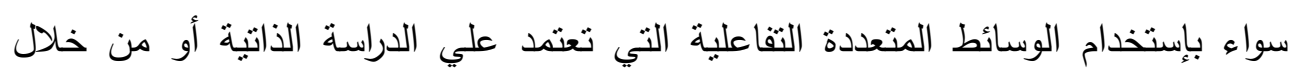


إستخدام الإنترنت وتوظيفها لصالح العملية التعليمية وأثنتت الدراسات السابقة فاعلية كلا الطريقتين في التعليم، ومن هنا كانت فكرة الدراسة الحالية والتي تهدف إلي الوقوف علي كل ما هو جديد فى العملية التعليمية خاصا بعد إعداد بنك المعرفة المصرى من قبل وزارة

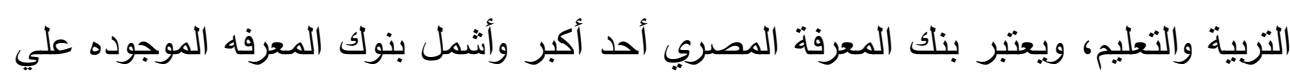
مستوي العالم نظراً لما يحتويه من مصادر معرفيه وتعليميه وتثقافيه وبحثنيه من أكبر دور

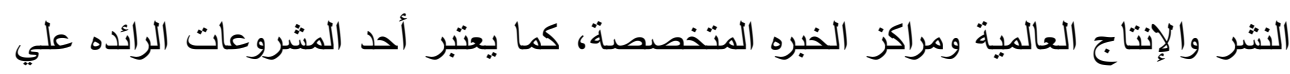
مستوى العالم من حيث الإتاحة علي المستوي القومي.

مشكلة البحث: The Study problem

إن استخدام الكمبيوتز في عملية التعلم والتعليم يعد من أحدث المجالات التي اقتحمها الحاسوب ومن المعروف إن المعلمين يقومون دائما بالبحث عن وسائل تعينهم على أداء وظائفهم التعليمية من أجل الوصول إلى تعليم أفضل؛ فتارة تستخدم الصور الملونة وتارة تستخدم الأشكال المجسمة كما تستخدم السبورات والكتب وبعض الفئ الأجهزة البسيطة. وفي السنوات الأخيرة ظهرت بعض الأجهزة الحديثة مثل أجهزة التسجيل

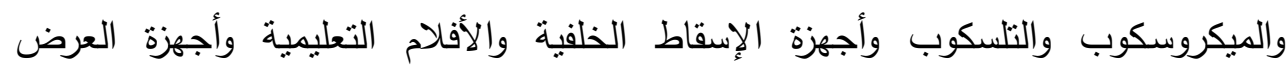
السينمائي وأجهزة التلفزيون التعليمي وغيرها ورغم تعدد هذه الوسائل وتتوعها فإن كل وسيلة تخدم هدفا محددا وقد تكون هذه الوسائل معقدة في تركيبها واستخدامها في بعض أنيان الأحيان

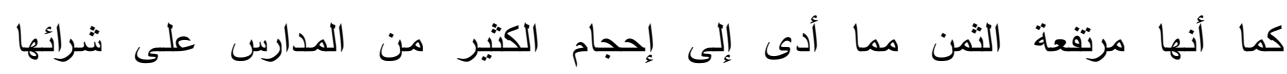

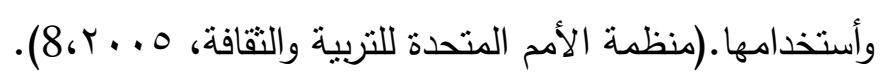

إن ظهور الجيل الثاني للشبكة العنكبوتية للمعلومات (الإنترنت) حيث أصبح تصميم المواقع على الثبكة أكثر تقدما، وتبادل المعلومات زادت سرعته بشكل كبير وهذه

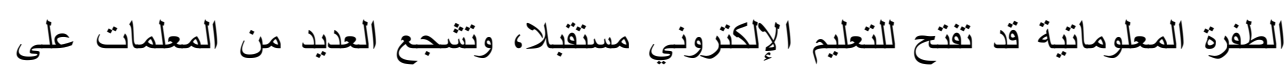

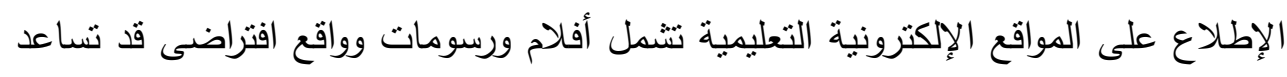
الطفل على فهم وأستيعاب بعض المفاهيم العلمية بصورة أفضل،كما أن هذا الأسلوب

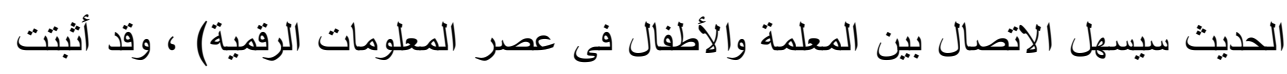


العديد من الدراسات العلمبة أن لإستخدام الحاسب الآلي أثر إيجابي كبير في الإرتقاء

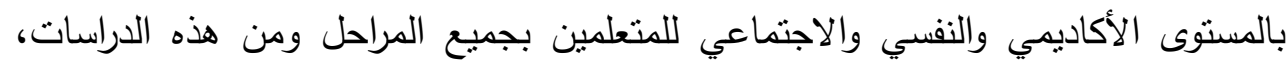

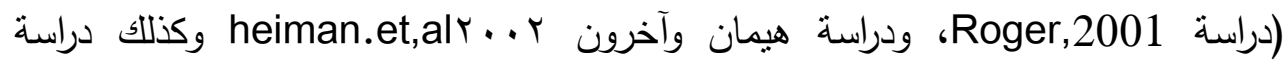

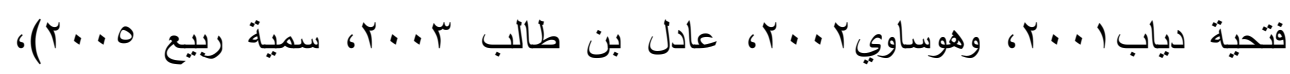

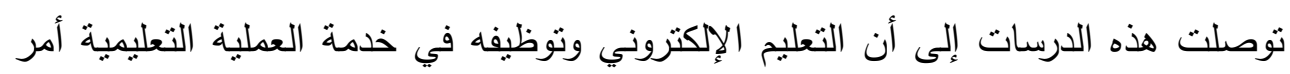

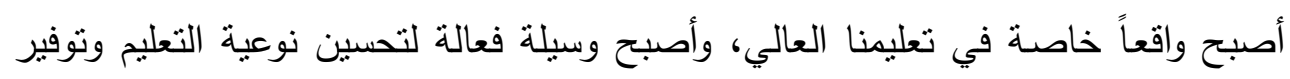

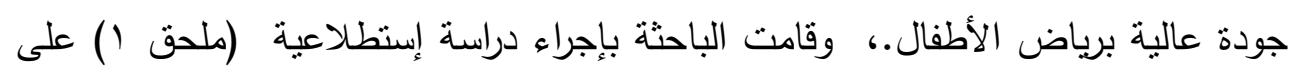

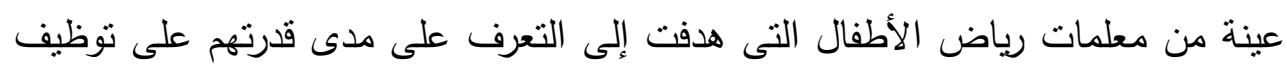

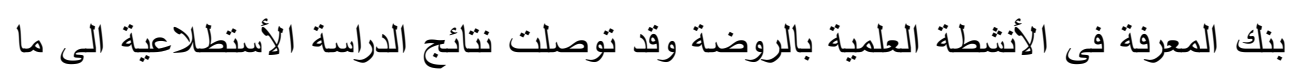
يلى

( ) أن نسبة كبيرة من المعلمات لديهن قصور فى الوعى بتوظيف ببنك المعرفة وكيفية توظيفة فى الأنشطة العلمية.

r ب توفر موقع هام على الإنترنت وعدم الإستفادة منه فى مجالى العلوم والرياضيات برياض الأطفال.

r) قله الوعى بالأستفادة من بنك المعرفة فى توظيف العديد من المواقع الأفتراضية

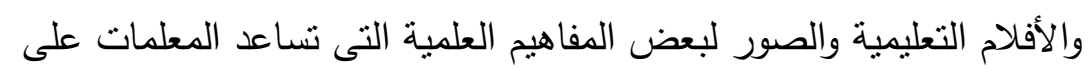

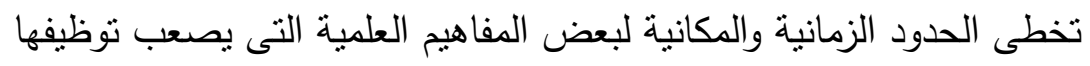

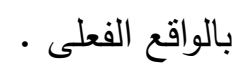
ومن هنا إنبتقت المشكلة ونبعت فكرة البحث الحالى فى تقديم إستراتيجية مقترحة لتوظيف بنك المعرفة فى الأنشطة العلمية لطفل الروضة. ويالتالى يحاول البحث الحالى الإجابة عن الأسئلة التالية: ا. ـ ما الجوانب المعرفية التى تحتاجها المعلمات لتوظيف بنك المعرفة فى الأنشطة العلمية؟

r. ما المهارات التى تحتاجها المعلمات لتوظيف بنك المعرفة فى الأنشطة العلمية ؟ 
r. ما الإستراتيجية المقترحة لتوظيف بنك المعرفة فى الأنشطة العلمية برياض

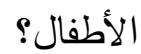

أهداف البحث:The Study Objectives يهدف البحث الحالي تحقيق ما يلى:

1. المساهمة فى رفع وعى المعلمات بإستخدام بنك المعرفة فى الأنشطة العلمية.

r. اقتراح أستراتيجية لتوظيف بنك المعرفة فى الأنشطة العلمية برياض الأطفال.

r. طرح فكرة بنك المعرفة كحل أساسي لتطوير المستوى التعليمي ليواكب التطور

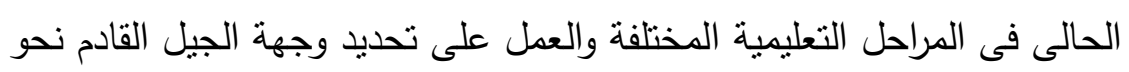

$$
\text { مجتمع ناجح فعال. }
$$

\section{أهمية البحث: The Study Significance}

ا. ـرفع الوعى المعرفى لمعلمات رياض الأطفال بتوظيف بنك المعرفة فى الأنشطة

$$
\text { العلمية. }
$$

r. توجية الباحثين والخبراء والمهتمين بتطوير العملية التعليمية فى كافة المراحل

التعليمية فى تدريب المعلمات على كيفية توظيف بنك المعرفة فى الأنشطة

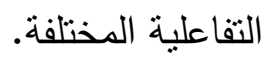

\section{منهج البحث: The Study Methodology}

تستخدم الباحثة فى هذا البحث المنهج الوصفى التحليلى لمناسبته لهذا البحث.

أدوات البحث: The Study Tools تحددت أدوات البحث الحالي فيما يلى :

1 ـ إسنطلاع راى المعلمات عن مدى قدرتهم على توظيف بنك المعرفة فى الأنشطة

$$
\text { العلمية بالروضة. }
$$

r. أستبيان لمعرفة الوعى (ببنك المعرفة المصرى) لدى معلمات رياض الأطفال. 
r. أستراتيجية مقترحة لتوظيف بنك المعرفة فى الأنشطة العلمية لدى معلمات رياض الأطفال.

(جميع الأدوات السابقة إعداد الباحثة)

حدود البحث: Limits of study يلتزم البحث الحالي بالحدود التالية : - - حدود جغرافية: أقتصر البحث على المعلمات برياض الأطفال (بمحافظتى القاهرة

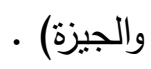

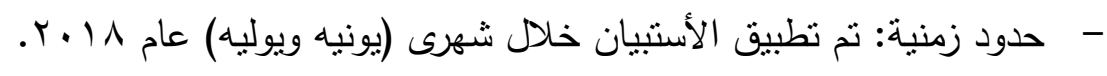

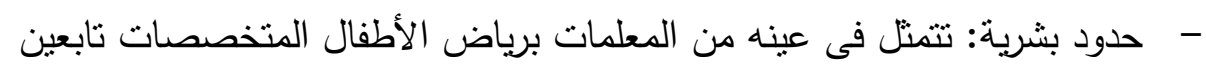
لإدارتى القاهرة والجيزة.

عينة البحث: the Study Sample:

تكونت عبنة البحث من معلمات رياض الأطفال المتخصصات التى بعملن

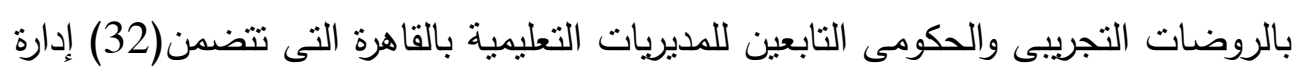

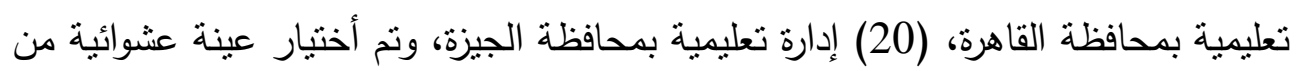

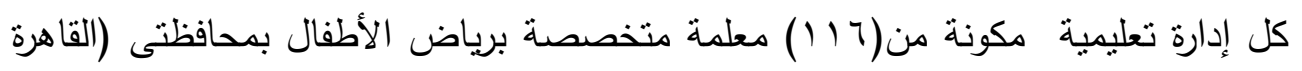
والجيزة)، تضمنت عدد حوالى( ع Vعلمة) بمحافظة القاهرة و (Y ع معلمة) بمحافظة الجيزة.

مصطلحات البحث: The Study Terms

الأستراتيجية The strategy : "الاستراتيجية هي تلك القرارات التي تهتم بعلاقة

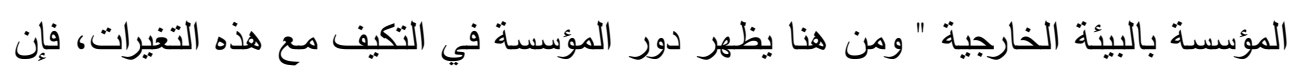

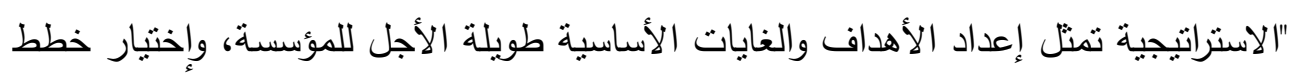

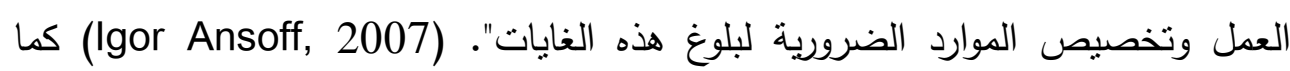
عرفها (Chandler, 2002): "هي تحديد الأهداف طويلة الأجل وتخصيص الموارد لتحقيق هذه الأهداف. 
التعريف الاجرائى للأستراتيجية : بأنّها مجموعة من القواعد والمبادئ التي ترتبط

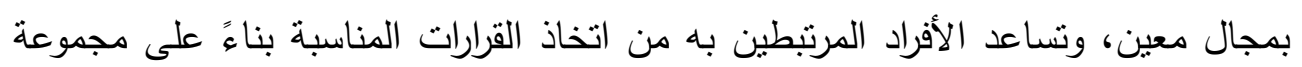

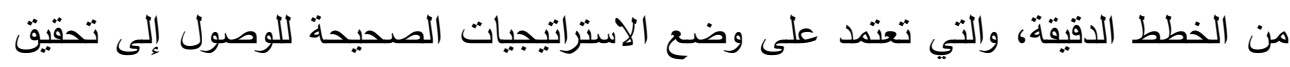
نتائج ناجحة.

بنك المعرفة المصري EKByptian Knowledge Bank):

هو أكبر مجموعة في العالم من الموارد التعليمية المتاحة عبر الإنترنت، حيث

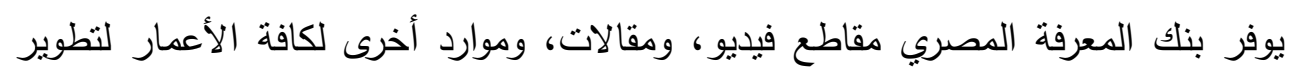
معارفهم ومهاراتهم في إطار القرن الحادي والعشرين. /https://discoveryeducation.ekb.eg/about-ekb

الأنشطة العلمية Scientific activities:

ويعرفها (فيجوتنكي Vygotsky ) بأنها أنشطة بها بعض المفاهيم العلمية التي تتمو نتيجة تهيئة مواقف تعليمية سواء كانت من جانب الفرد ذاته أو من مصدر خارجي، ويلاحظ أن فيجوتنكي يركز على طريقة اكتساب المفاهيم، ومن هذا التعريف نرى أيضا أن الطفل الذي تتاح له الفرصة لروئة أثنياء متتوعة ويتواجد مع أثخاص كثيثين الثين ومختلفين يتكون لديه

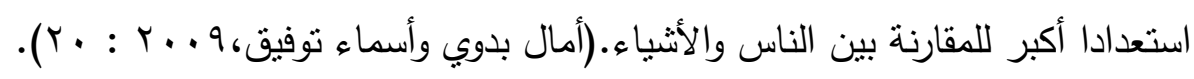

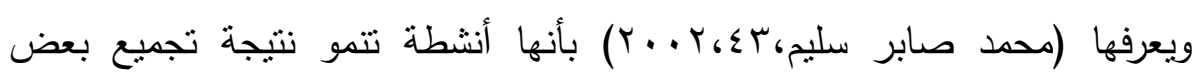
المعلومات المشتركة لمجموعة من الأحداث والأشياء. التعريف الإجرائى للمفاهيم العلمية برياض الأطفال :هي البرامج والخبرات والأنشطة

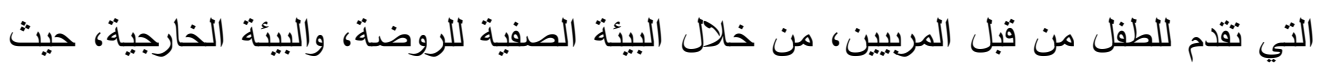

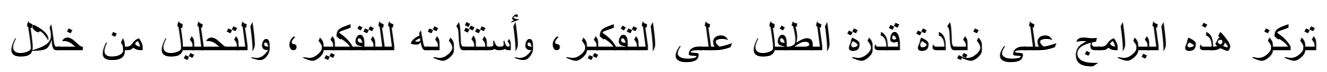
الملاحظة. 
الأطلر النظرى والدراسات السابقة للبثث : ويتناول هذا الجانب المحاور التالية : المحور الأول : أستراتيجية توظيف بنك المعرفة برياض الأطفال: عندما نحدد الإستراتيجية من خلال إعطاء تعريف لها فإن هذا لا يعني بالضرورة تحديد أو حصر المجال للإستراتيجية كعلم. والإستراتيجية تختلف عن جميع العلوم، حيث ديث بإمكانها الاستفادة من جميع العلوم: فهي بحاجة للعلوم التجريبية من أجل تطوير وتقييم

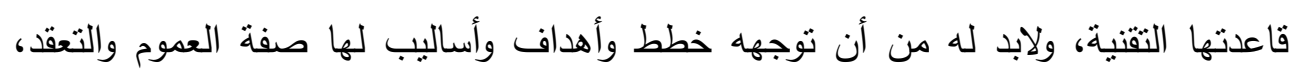
وكلها يطلق عليه اسم استراتيجية ، واستعير مصطلح الإستراتيجية في مجال علم النفس وله

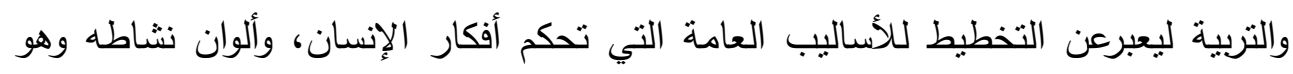

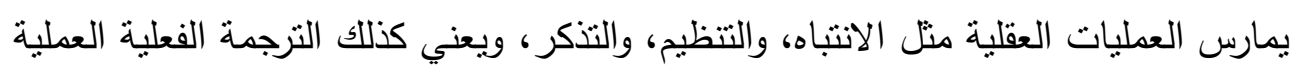
للأهداف الكبرى لعملية التربية وهو بهذا يقترب كثيراً من فلسفة التربية التي تعد الأطار

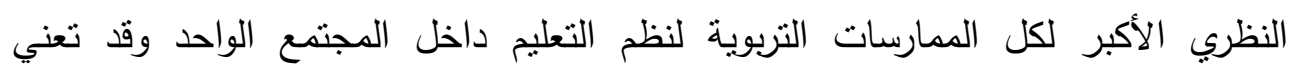
الاستراتيجية التخطيط العام لأهداف عامة نسبياً، يتضمن اختيار المادة الملائمة، والتتظيم

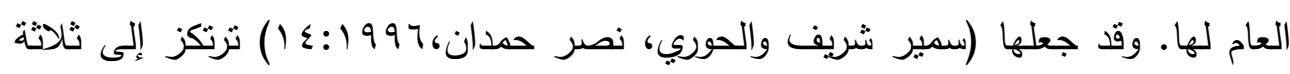
أركان، هي: التخطيط والتتفيذ والتقويم.

الإستراتيجية بالنقل الحرفي للكلمة الإنجليزية Strategy، هي خطط أو طرق

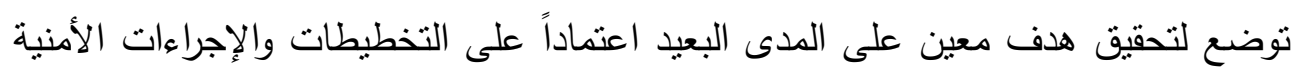

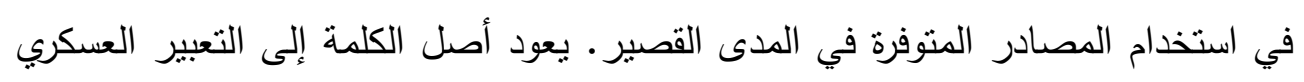
ولكنها الآن تستخدم بكثرة في سياقات مختلفة مثل سياقات العمل والتسويق وغيرها الخ. أصل الكلمة:الإستراتيجية: (C. Kennedy, 2002:7) تعني أصول القيادة الذي لا إعوجاج فيه، فهي تخطيط عال المستوى، فمن ذلك الإستراتيجية العسكرية أو السياسية

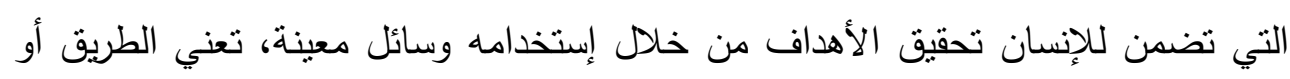
الإستراتيجية، فهي علم وفن التخطيط والتكتيك والعمليات، ثم استعملت هذه الكلمة في المجالات المتعددة في شتى مناح الحياة العامة. 
Strato الإستراتيجية :تعد من المصطلحات القديمة المأخوذة من الكلمة الإغريقية وتعني الجيش أو الحشود العسكرية، ومن تللك الكلمة اشتقت اليونانية القديمة مصطلح Strategies

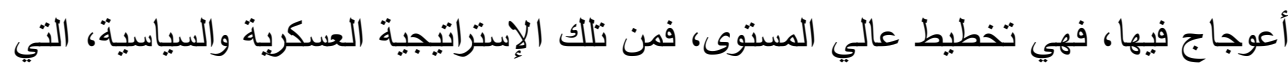

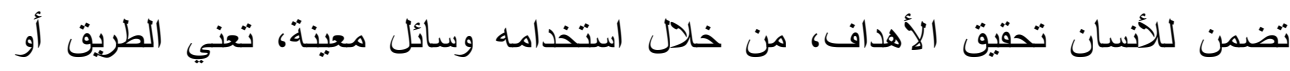

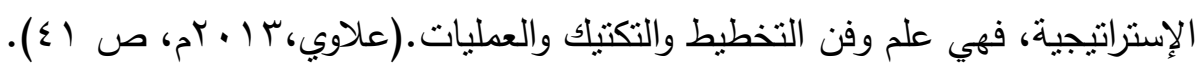

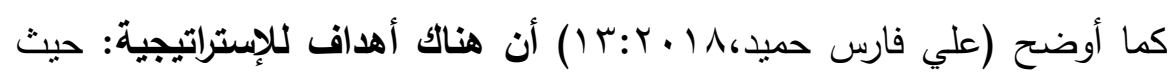
تهدف الإستراتيجية إلى تحقيق هدف السياسة عن طريق الإستخدام الأمتل لكافة الإمكانات

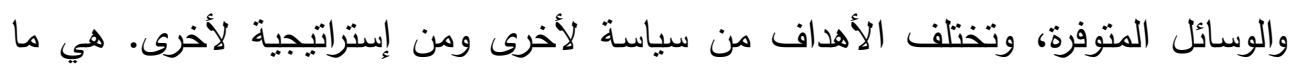
يسمى بالأهداف الإستراتيجية. والإستراتيجية الناجحة هي التي توفق إلى إختيار الوسيلة أو

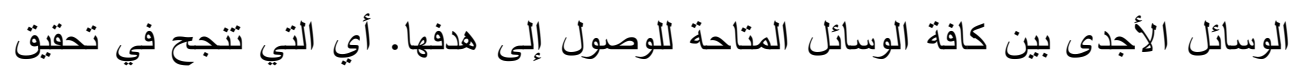

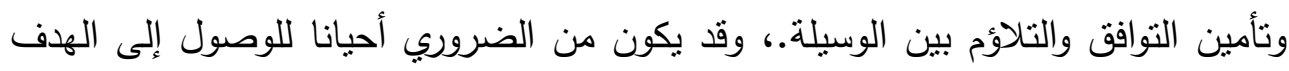
النهائي للسياسة تحديد تحقيق عدد من الأهداف المرحلية التي يؤدي تحقيقها إلى أحداث تغييرات هامة لتحقيق الهدف النهائى.

وهناك عدة وظائف للإستراتيجية كما أوضحها (محمد نصحى ابراهيم، 10 • ب)

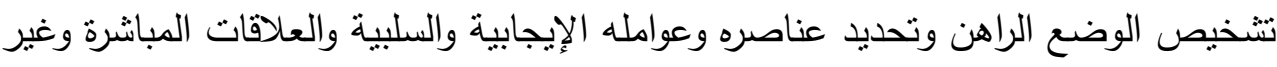
المباشرة بين هذه العوامل إيجابا وسلبا.، وتحديد القوى والوسائل المتاحة واختيار الأكثر لرائر

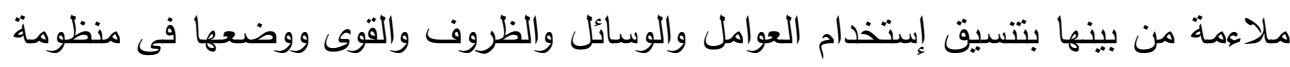
واحدة مترابطة تحقق التكامل والتفاعل مع مراعاة المواءمة مع المواقف المتغيرة والمرونة

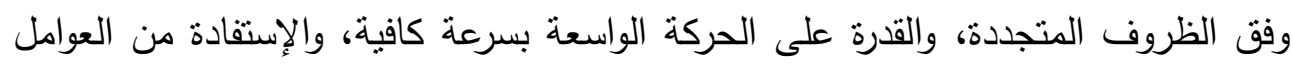

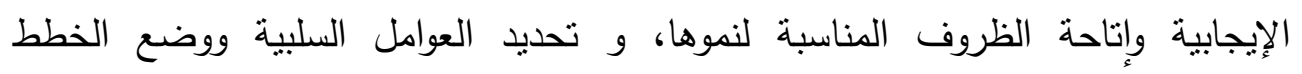
والظروف الملائمة لحصرها.

وتتعدد أنماط الاستراتيجيات ويتفق كل منها مع أهمية الهدف الذي توضع من أجلة

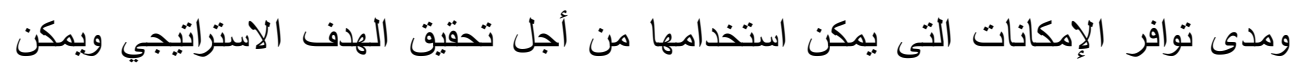

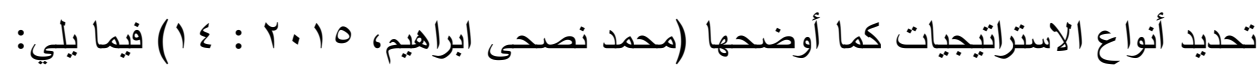


1- الإستراتيجية العقلانية: وهذه الاستراتيجية تعتمد على البحث العلمي وعلى تولى الكفاءات العلمية لوضعها، وللنهوض بمتطلباتها وقيادة حركة التغيير المنشوده منها، كما تعتمد على الأساليب الحديثة فى الإدارة والتتظيم. فأنثارات

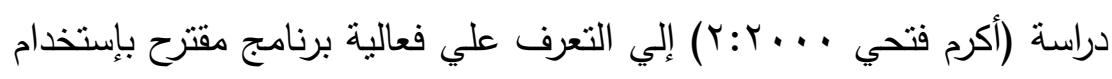
بعض الإستراتيجيات من خلال الوسائط المتعددة التفاعلية لمحو الأمية الكمبيوترية و تتمية الاتجاه نحو إستخدام الحاسوب وأسفرت نتائج هذه الدراسة

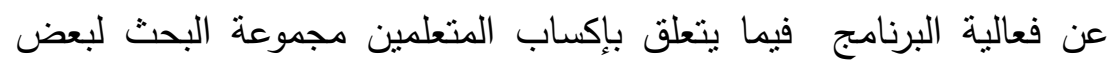

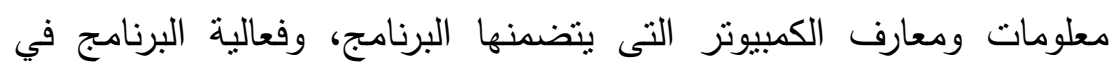
إكسابهر المهارات التي يتضمنها البرنامج وفعاليته في إكسابهم إتجاهات ايجابية نحو الكمبيوتر •

r - الإستراتيجية التوجيهية: وهى تعنى بالدعوة والإقناع وكسب التقة وتتمية الروح

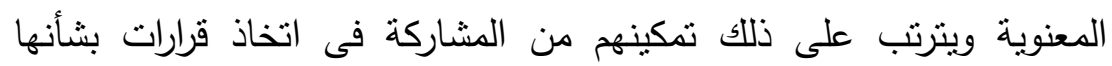
وإنراكهم فى عملية وضع هذه القرارات والاعتماد على تعاونهم فى تطويرها كما تراعى هذه الاستراتيجية خصائص التقافات والقيم الاجتماعية السائدة بين

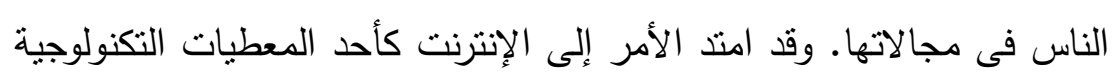
الحديثة التي فرضت نفسها على ساحة الحياة العصرية بما تحمل في جعبتها

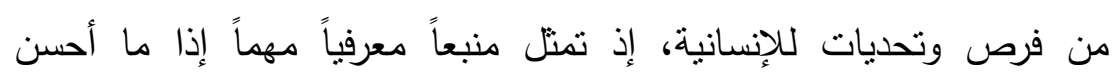
استخدامها، إلا أن شبكة الإنترنت قد تشكل أيضاً تهديداً خطيراً للقيم الأخلاقية

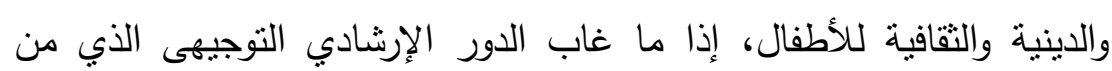

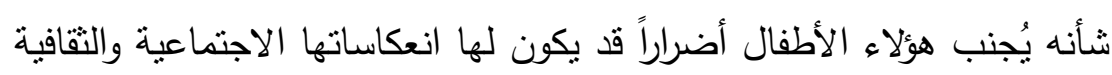

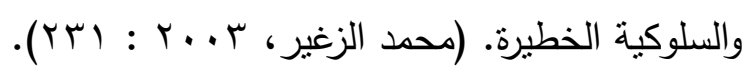

r- الإستراتيجية السياسية الإدارية: تعتمد على القوة النابعة من السلطة السياسية أو الإدارية وتفترض فى الناس المعنيين بها المطاوعة لمطالب السلطة الإدانة

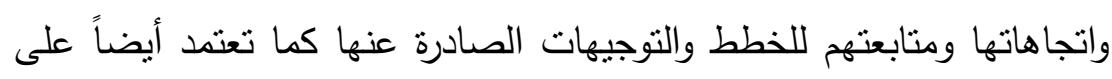


التشريعات الحكومية وما يترتب عليها من توجيهات وتعليمات. (محمد هانى

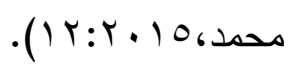

ومن الأفضل أن تكون الإستراتيجية المعتمدة للتفيذ يتكامل فيها الأنواع الثناث من الإستراتيجيات والإستفادة من مزايها وتجميعها فى الإستراتيجية المتبعة فى الهدف المراد الهنداد

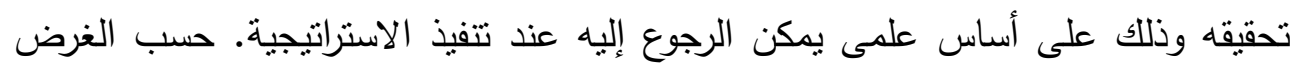

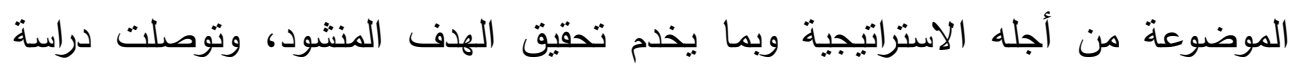
Coffman , Teresa)

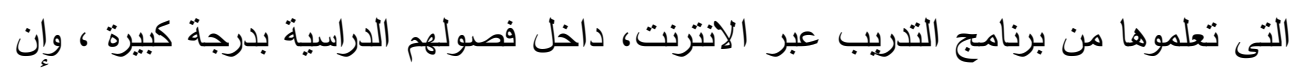
برنامج التتمية المهنية المقدمة عبر الإنترنت يدعم الاعتماد على مداخل التعلم المتمركزة حول المتعلم والتى تتجع الاكتثاف الذاتى، والششاركة الفعالة، والتعاون بين الأقران

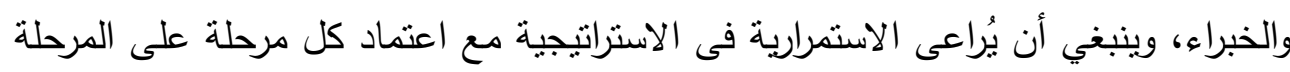

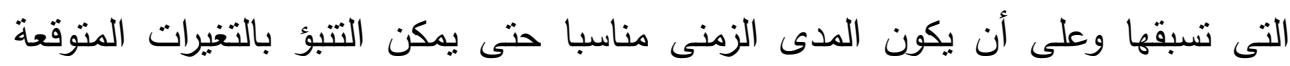

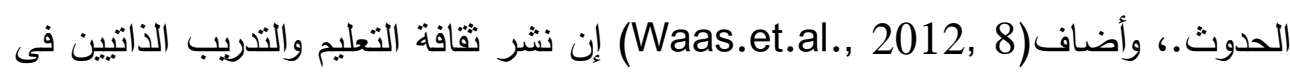
المجتمع والتى تمكن من تحسين ونتمية قدرات المتعلمين والمتدربين بأقل تكلفة وبأدنى

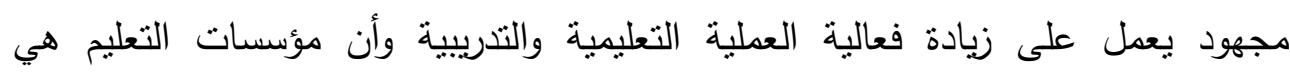
المؤسسات المسئولة عن قيادة المجتمع نحو مستقبل مستدام عن طريق تقديم المعرفة، التدريب، تعليم القادة وتعزيز التقدم والمشاركة المجتمعية، من خلا نظام تعليمى حديث ومتطور

ولا يمكن أن يكون هناك نظام تعليمي منطور من دون أن يكون هناك معلم متميز

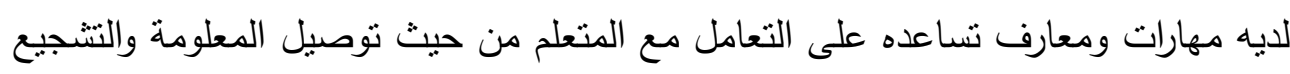

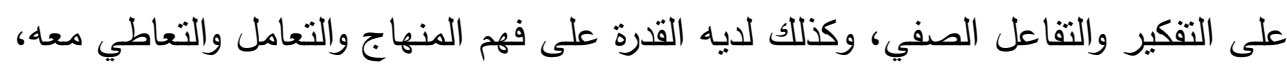

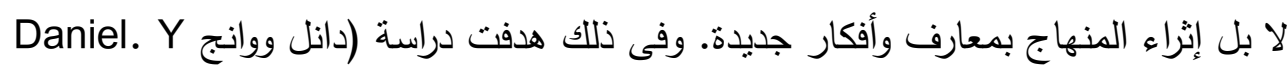

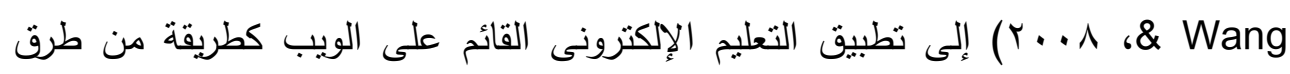
التعليم الفعالة، وأثنتت الدراسة فعالية بيئة التعليم الإكترونى، وأكدت دراسة الإنئ (حنان خليل،

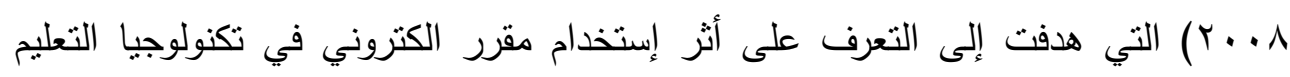




\section{المجلة العلمية لكلية رياض الاطفال - جامعة اسيوط}

لتتمية الجوانب المعرفية والأدائية لدي طلاب كلية التربية، وتوصلت نتائج الدراسة إلى فعالية الموقع التعليمي في تتمية التحصيل المعرفى والأداء المهارى.

بيد أن التعليم ليكتسب هذا التأثنر ويتقلد هذا الدور المحوري يجب أن يكون تعليماً

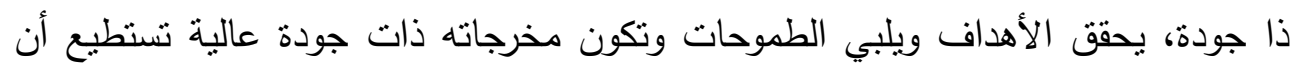
تتافس في سوق العمل العالمي، ويتمتع خريجوه بالحد الأدنى من الكفايات والمهارات

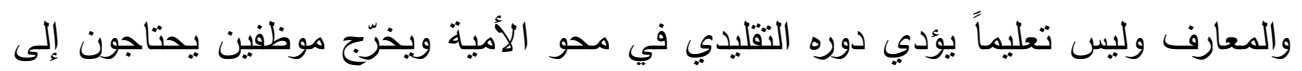

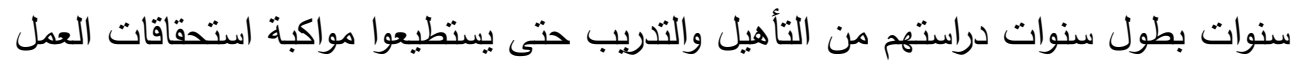

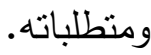

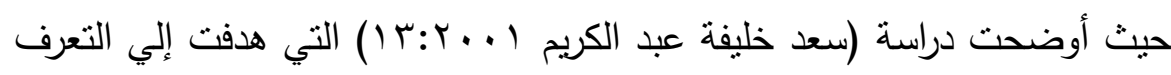

علي أثز التعلم الفردي الذاتي باستخدام أسلوب الوسائط المتعددة والمنطورة، والحقائب التعليمية في التحصيل والتفكير الإبتكاري لدي طلاب شعبة الأحياء بالفرقة الثانية بكلية

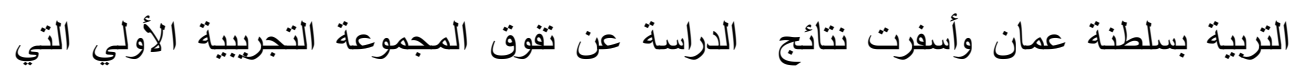
درست باستخدام التعلم الفردي باستخدام الوسائط المتعددة في التحصيل والتفكير الإبتكاري لهني

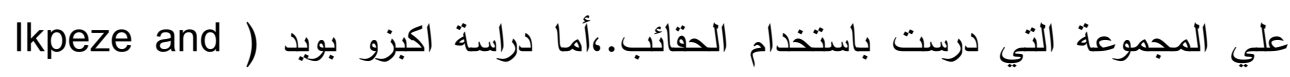
2007,Boyd تعليم العلوم من خلال خلق بيئة تعلم تسمح بإحداث التفاعلات المثمرة والنشطة، وقياس اثر الثربه

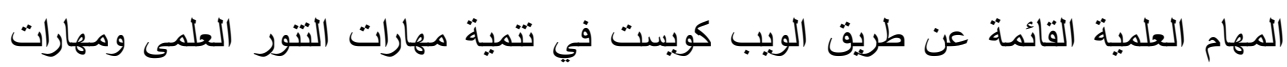
التفكير عالي الرتبة لدي طلاب الصف السادس الابتدائي , فقد توصلت إلي فاعلية إستخدام الإنترنت والويب كويست ونجاحها خاصة عندما تكون الأنشطة مختارة جيدا وبعناية وبطريقة منظمة، وتعتبر المعامل الافتراضية والمواقع الإلكترونية من أهم تطبيقات التعليم الإككتروني

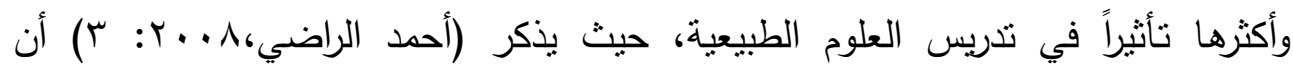

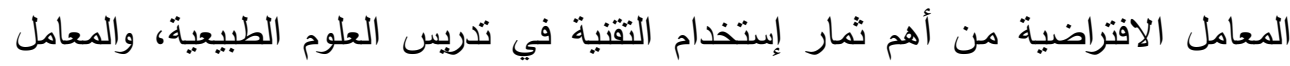
الافتراضية هي معامل مبرمجة تحاكي المعامل الحقيقية وهي تمكن المتعلم من إجراء تجارب معملية شبه واقعية، ويمكن من خلالها إجراء التجارب بأي عدد من المرات يحتاجه المتعلم كما نساعد علي سد العجز في الأجهزة المعلية كما يمكن تغطية معظم الأفكار 


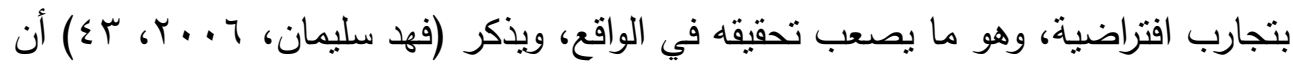

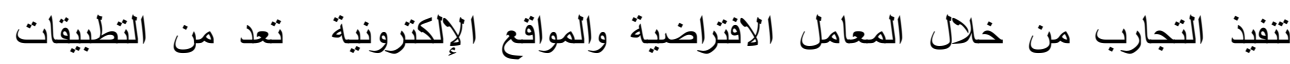
الرئيسية لإستخدام التقنية وأوسعها استخداماً في تدريس العلوم و تشهم في تتمية المهارات

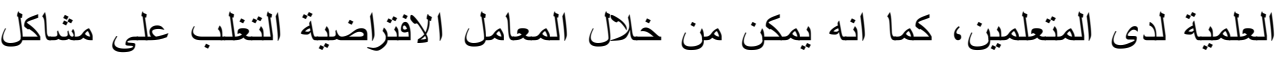

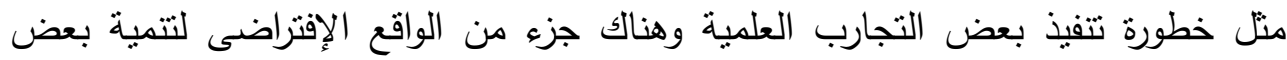
المفاهيم العلمية ببنك المعرفة المصرى التى يمكن توظيفها مع طفل ماقبل المدرسة وتبسيطها بشكل فعال معهم.

بعد وضوح الرؤية الفلسفية والفكرة النظرية لبنك المعرفة لا بد من رؤية استراتيجية

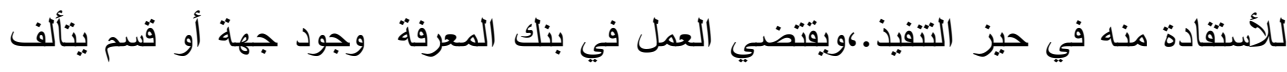
من فريق تربوي تعليمي فني. يقوم على :إعداد الخطط القريبة والبعيدة المدى لتطبيق التعليم الإكتروني ومتابعة هذه الخطط، تدريب المعلمين، و توجد حاجة ماسة لتدريب المتعلمين

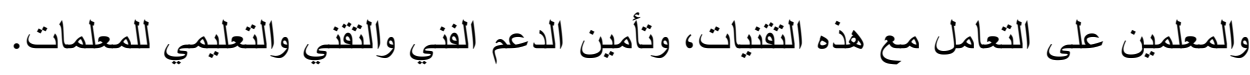
مكونات بنك المعرفة (أهميتة -أهدافة- محتواه) :

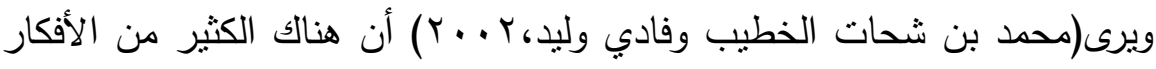
التي يتجاذب المعنيون بالتربية والتعليم حول الأدوار والمهام أو الوظائف التي يمكن أن أن

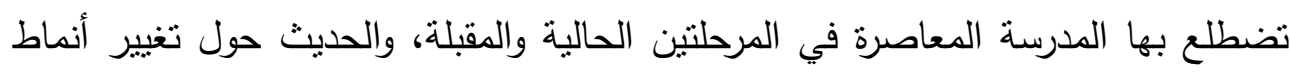
التربية وأسالييها وآلياتها لا ينتهي عند حد ولا يعرف حدوداً جغرافية معينة دون غيرها.

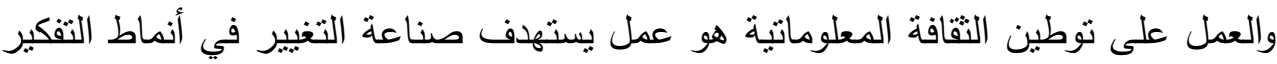
التربوي القائمة في المدرسة وفي البيت وفي المجتمع برمته. ويهتم بنك المعرفة ببناء مجتمع متعلم عن طريق إناحة العلوم والمعارف الإنسانية بشكل ميسر لكل مواطن مصري علي ارض مصر، ويعد بنك المعرفة هو أكبر مكتبة رقمية في العالم تتكون من المحتوي المعرفي لأكبر دور نشر في العالم مثل (سبرنجر نيتشر، وناشيونال جيوجرافيك، وديسكفري، وايلسفير، وكامبريدج، واكسفورد، وطومسون رويترز ، والعشرات من الناشرين https://sdl.edu.sa/SDLPortal/ar/post.aspx?p=9142 . 
يهاف بنك المعرفة تنقيف وتعليم كل المصريين بالمجان، وإتاحة المحتوى العلمي

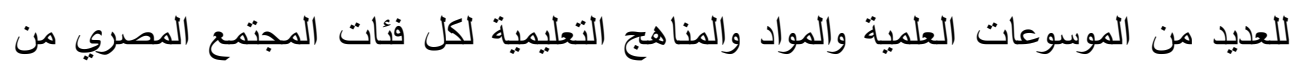
المواطنين والباحثين والطلاب على اختلاف فئاتهم العمرية. حيث يجد الباحث الأكاديمي

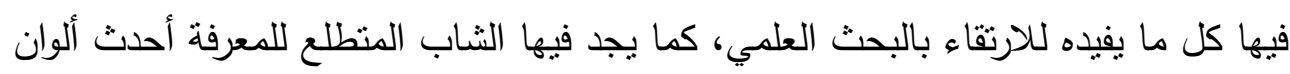

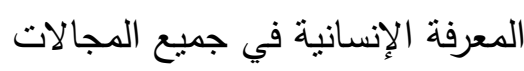
http://sis.gov.eg/section/2383/7179?lang=ar

يحتوي بنك المعرفة المصري علي أربعة مكونات /بوابات رئيسية وفقاً لإهتمامات

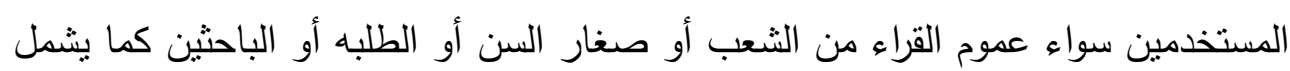
بنك المعرفة بوابة خاصه لصغار السن مدعمه بنظام تصفح بسيط وتصميم متميز للأطفال،

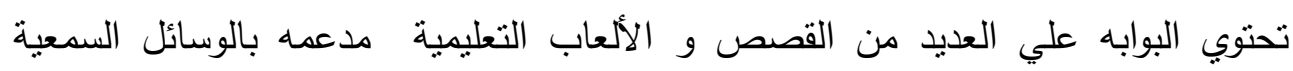
البصرية، بالإضافه إلي العديد من الخدمات الأخرى والتي تهدف إلي نشر الوني الوعي والمعرفة

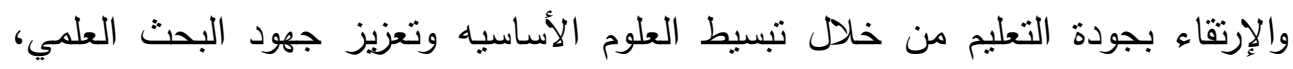

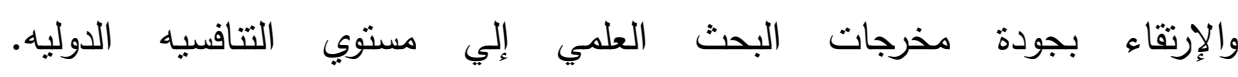
http://qalubiaedu.org/

وأثارت دراسه ميندز دانيل (Mendez Daniel,2014) إلى التعرف على أثر

التعلم بمساعده الكمبيوتز على التحصيل الأكاديمى فى فنون اللغات حيث أسفرت النتائج على دانى

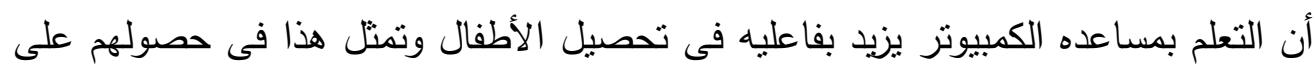

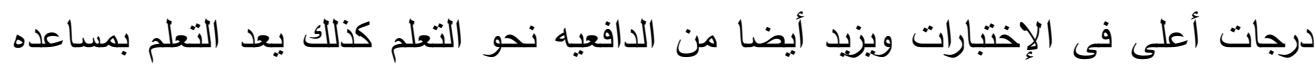
الكمبيوثر أحد أهم عوامل الحفز التى تدفع الطفل إلى الإنجذاب والإندماج فى التعلم. ويستقبد البحث من تسليط الضوء والأستفادة من (بنك المعرفة) لمعلمات رياض الأطفال فى الجانب الخاص بالمحتوى العلمى لتبسيط المفاهيم العلمية للأطفال من خلال من لهن عرض الفيديوهات و الوسائط الرقمية المتتوعة، كتب إلكترونية، مجلات وموسوعات إلكترونية، قواعد بيانات، الواقع الإفتراضى، والعديد من المصادر لبعض المفاهيم العلمية العنية لطفل الروضة. 


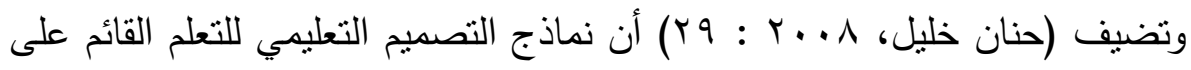
الإنترنت مُفيدة إذا صُمدت بشكل جيد ؛ لأن التصميم الجيد يضمن المحافظة علي استمرار اهتمام المتعلم وإثارة دافعيته لمواصلة التعلم، وتوصلت دراسة (49) :Hong,2003) إلي لإني فاعلية إستخدام الأنترنت في التعليم كوسيلة تعليمية، و وجود أتجاه إيجابي نحو استخدامه في

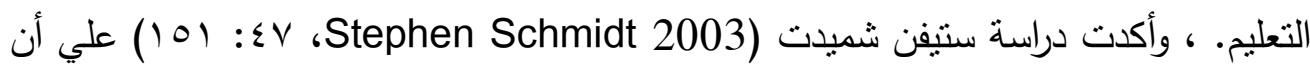
استخدام شبكة الويب في المدارس توفر للمتعلمين إمكانات جديدة وتعتبر أداة لمحاكاة الواقع، وقد توصل الباحث إلي أن نجاح التعلم بالمحاكاة أو التعلم الفعال علي موقع عبر الإنترنت يعتمد أساسا علي تلبية الأهداف التعليمية.

ومن هنا يتضح إن أساليب العمل المتتوعة التي يستخدمها الإنسان هي من الأمور

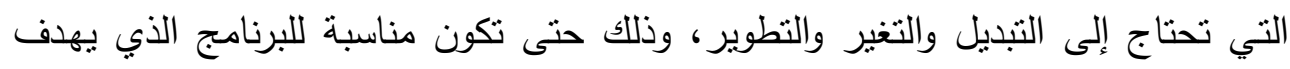
إليه، وهذا التتقيح والتطوير المستمر في الأساليب والإستراتيجيات من أهم مميزات التكنولوجيا فى العملية التعليمية.

المحور الثانى : المفاهيم العلمية برياض الأطفال وتوظيفها من خلال بنك المعرفة. لقد بات الربط بين جودة العملية التعليمية وإستخدام التكنولوجيا كأحد متطلبات

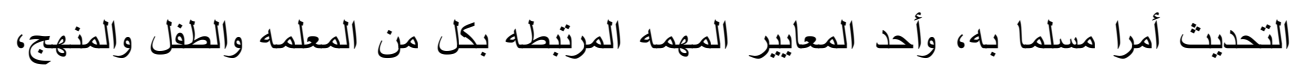
وإستخدام الكمبيوتر فى رياض الأطفال كأحد أدوات التكنولوجيا يشعر الطفل بالبهجة ومتعة بلهن

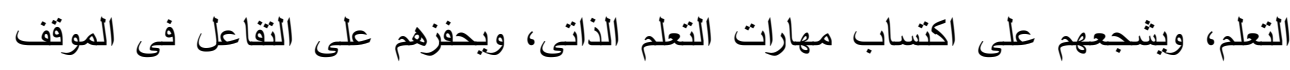
التعليمى، وييسر تقويم الموضوعات التى تتسم بالصعوبة والتجريد عن طريق أستخدام أساليب النمذجه والمحاكاه التى تعتمد على الصوت والصورة والحركة والألوان، بما يساعد على جذب إنتباه الأطفال وزيادة تركيزهم وبالتالى زياده مكتسباتهم.(نشرة وزارة التربية

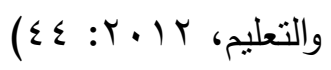

وتعتبر مرحلة رياض الأطفال من المراحل الحاسمة في تشكيل أساسيات شخصية طفل الروضة ووجود دور فعال لطفل الروضة ييعد به عن طرق الحفظ والتلقين والإلقاء

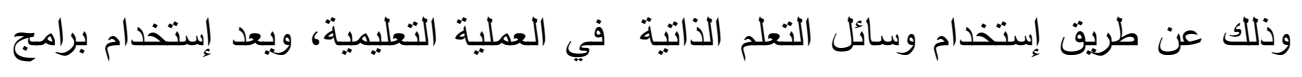


الكمبيوتز والتي تعتمد على دمج عناصر الصوت والحركة والألوان والنصوص المكتوبة وخاصة تللك البرامج تستخدم بصورة ناجحة مع الحقائق والمهارات والمفاهيم الأساسية

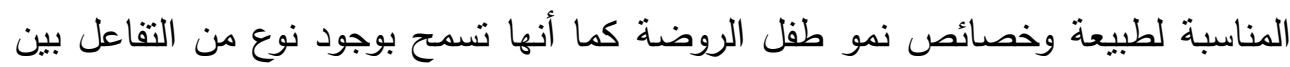
الطفل ومكونات البرنامج المستخدم.

ويهنم بنك المعرفة بمحاولة تجزئة وتبسيط المفاهيم الصعبة مثل المخترعات العلمية والظواهر الطبيعية للطفل وبذلك يسهل تقديمها له، ومن الدراسات التي أكدت على أهمية استخدام الكمبيوتز والوسائط المتعددة في اكساب الطفل المفاهيم المختلفة مثل: دراسة (لمياء

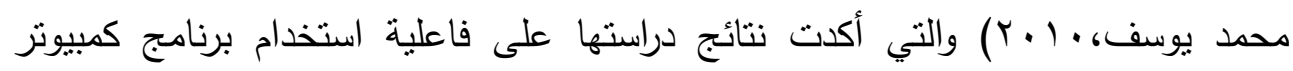

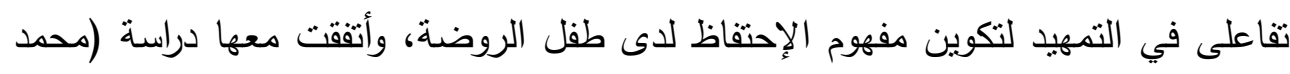

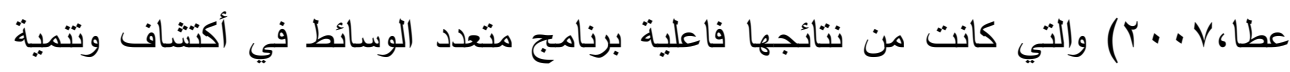
بعض مجالات الذكاءات المتعددة لاى طفل الروضة ومن ضمنها الذكاء العلمى وتتميته من خلال برامج الوسائط المتعددة.

وهذا ما دفع الباحثة الى كيفية إستفادة معلمات رياض الأطفال ببنك المعرفة فى جانب تبسيط بعض المفاهيم العلمية لطقل الروضة.

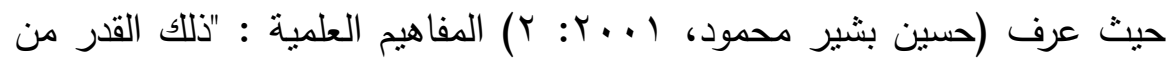

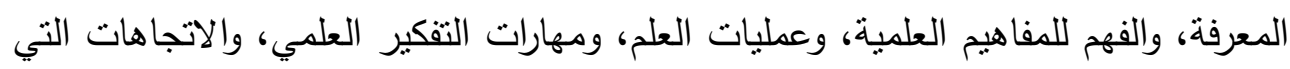
تجعل الفرد قادراً على المشاركة، واتخاذ القرارات المناسبة في حياته اليومية. وهذا يعنى أن ولن أنهات الثخص يكون قادراً على أن يكون لدية القدرة على أن يصف، ويشرح، ويحلل الظواهر ،

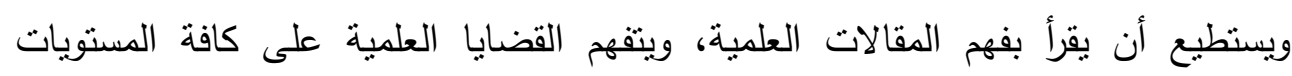
العلمية، والقومية، والوطنية، وأن يكون لديه القدرة على أن يقيم المعلومات، والمعرفة العلمية".

وتعليم المفاهيم العلمية يكسب الطفل كثيراً من المعلومات العلمية المفيدة عن بيئته التي يعيش فيها. وتجعله على اتصال مبانر بالطبيعة التي يستمد منها حياته ورزقه وراحته

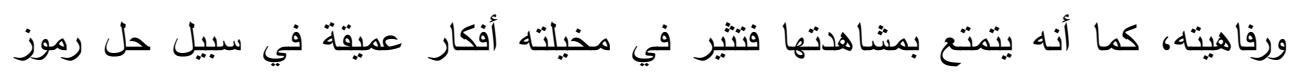


المشاكل التي تعترض سبيله كل يوم. ويزيد إدراكه للعلاقات التي تربط مختلف المخلوقات

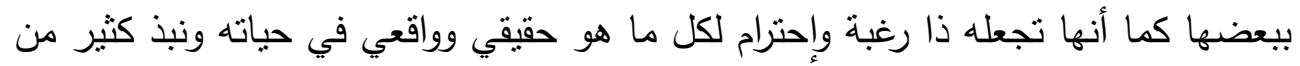

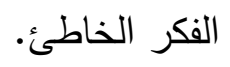

وتساعد العلوم الأطفال على تميز الأشياء وفهمها كما هي في الحقيقة وكذلك

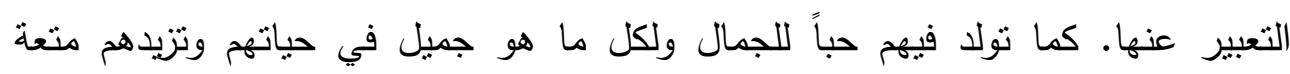

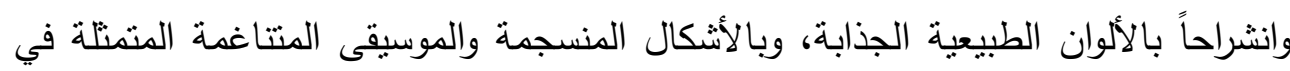
كل مظهر من مظاهر هذا الكون المدهش. إن العلوم تسهم بمقدار كبير في نمو المفاهيم العلمية والرياضية للأطفال وتساعدهم على التفكير العلمي في شتى المجالات وتتمي القدرة

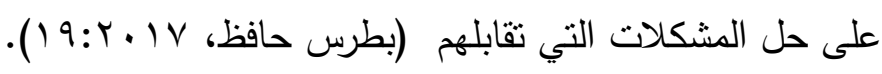

لذا نجد أن هناك أهمية لتعلم المفاهيم العلمية لطفل الروضة فى مساعدة الطفل

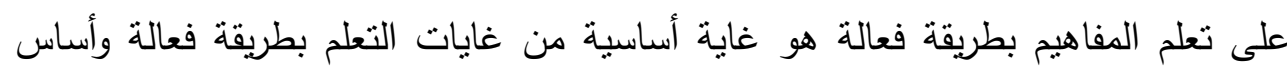

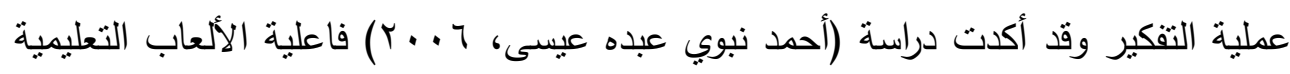

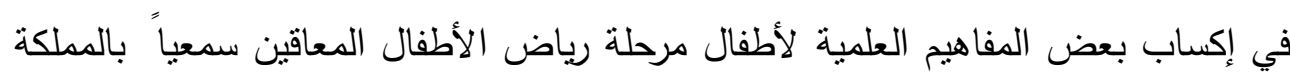

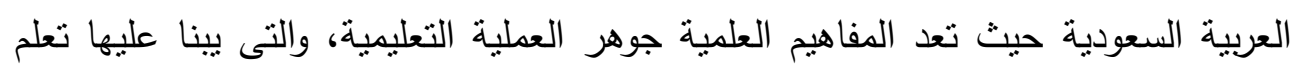

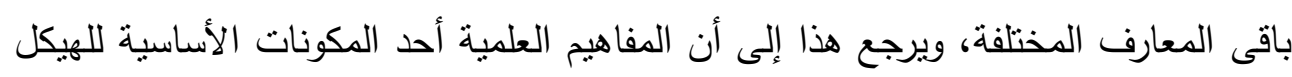

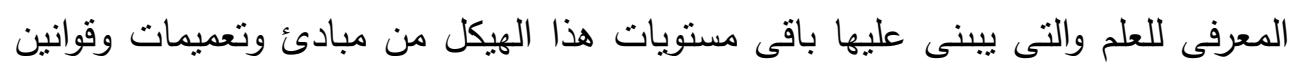

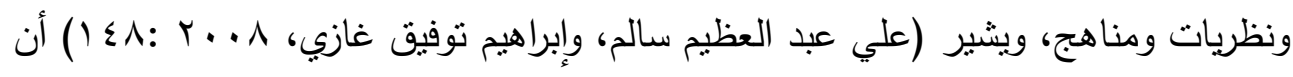

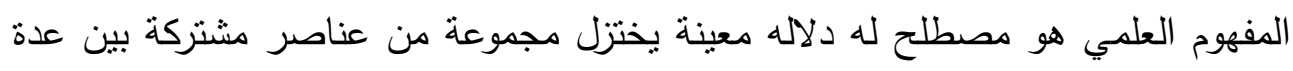

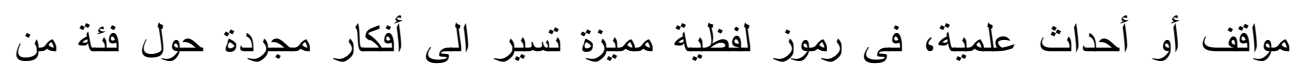

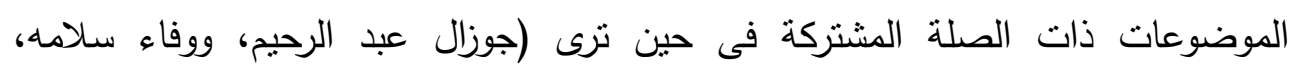

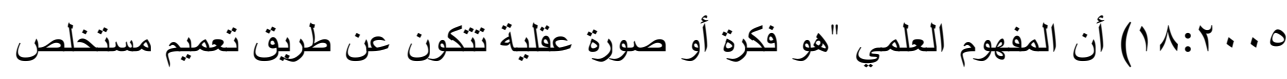
من الحقائق"، ويعد تعلم المفاهيم العلمية هدفا من أهداف تعليم العلوم فى جميع مراحل التعليم حيث أنها وسيلة للتحرر من الخوف والخرافة والسيطرة على الطبيعة والتخطيط للمستقبل، ومعرفة المعلومات والمفاهيم من أهم الركائز التى تؤدي الى تتمية مهارات التفكير

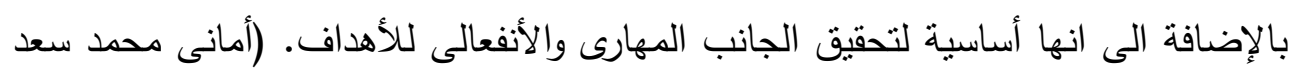




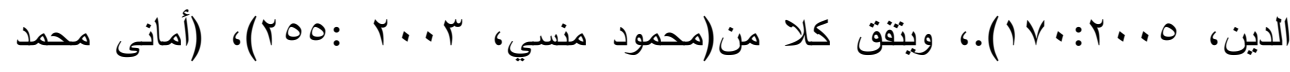

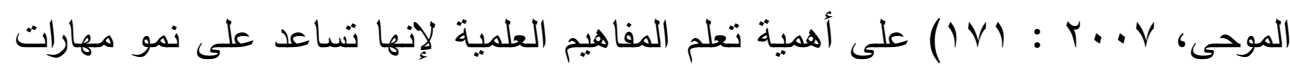

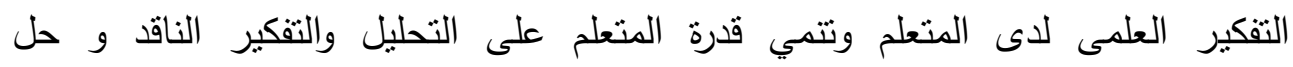

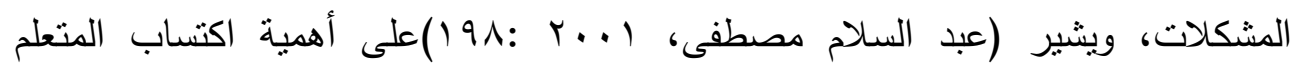
للمفاهيم العلمية الصحيحة حيث تساعده على فهم المادة العلمية وتتقله من المعرفة البدائية

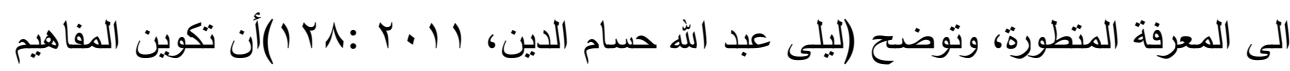
العلمية يتأثز بعاملي النضج والخبرات المتوفرة لديه، وأن الأفراد يختلفون فيما بينهم من حيث الثين

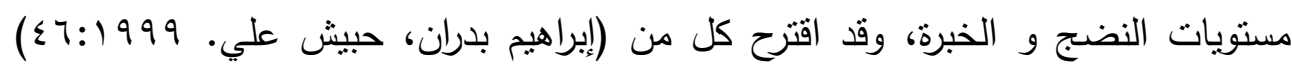

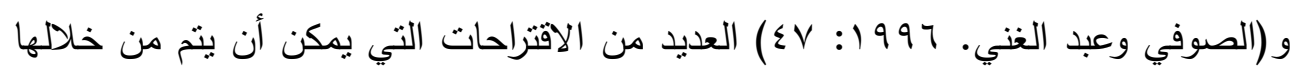

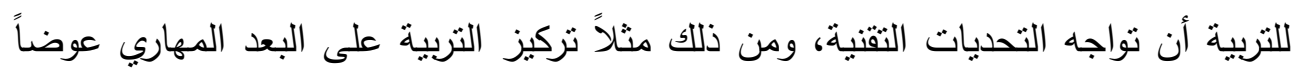
عن البعد التلقيني للمعلومات، والعناية بالإبداع والمبدعين، والقيام بدور كبير في التتوير تلتير

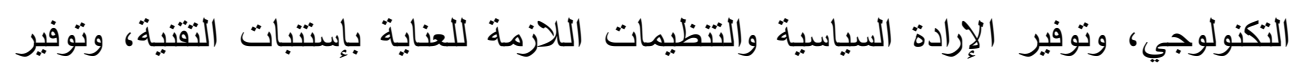
البرامج والسياسات العلمية التكنولوجية، وتطوير النظام التعليمي عبر مدارسه وكلياته ومعاهده وجامعاته ومختلف مؤسساته.

ويهدف بنك المعرفة إلى تفعيل التعليم والإستفادة من مجالات التقنية وتهيئة

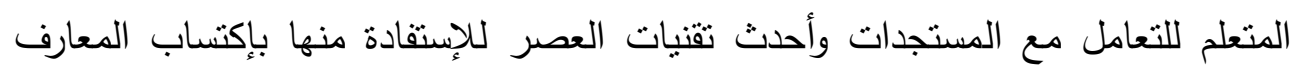
وتطويرها وتحديثها وتتمية المهارات وصقل التوجهات. للوصول إلى تعليم عصري فعال ومتابعة المستجدات على مستوى التقنيات والإتصالات وإستغلالها لنطوير عمليتي التعليم

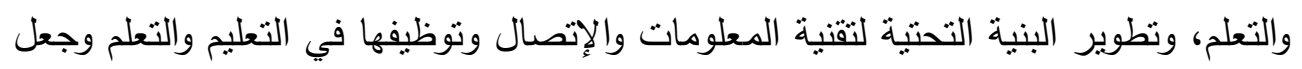
العملية التعليمية أكثر تتويقا وأقرب للإستيعاب ومتابعة تطور المعارف كمّاً ونوعاً.

\section{توظيف بعض المفاهيم العلمية لطفل الروضة من خلال بنك المعرفة :}

تَزَخَر المختبرات حالياً بالعديد من الأجهزة الحديثة والرقمية، والتي لها الفضل

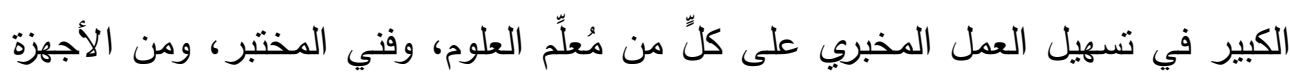

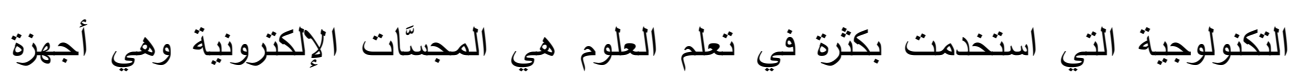
تُساعد على رصد استجابات دقيقة لنتائج التجارب إلى جانب ذلك قام الخطيب بإعداد ورقة 
للمؤتمر العربي الدولي الأول للتعليم في الوطن العربي الاستثمار في جيل المستقبل " التعليم

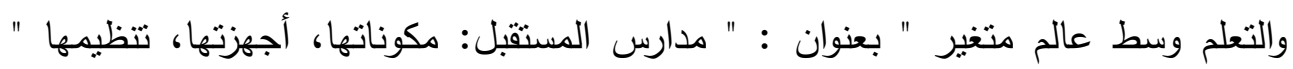

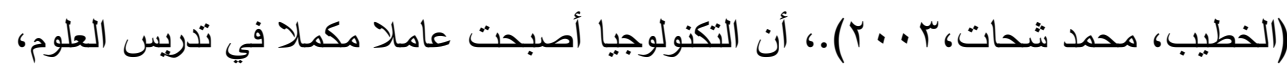
وتعتبر أداة ومهارة وعملية في تدريس العلوم، وأنه ينبغي أن يعرض الأطفال عند دراستهم

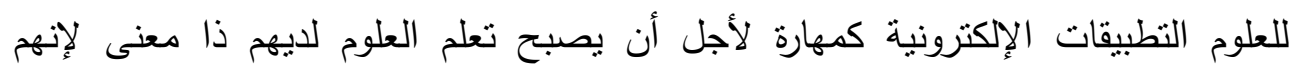
قادرون على استخدام تكنولوجيا الحاسوب للبحث عن إجابتهم خلال العمل الاستقصائي.

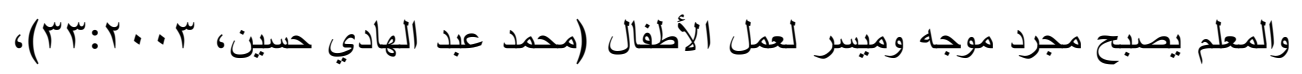

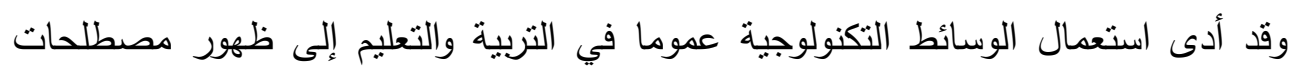
جديدة مثل: "التعليم الافتراضي" والتعليم الالكتروني (électronique education) ويشير لئير

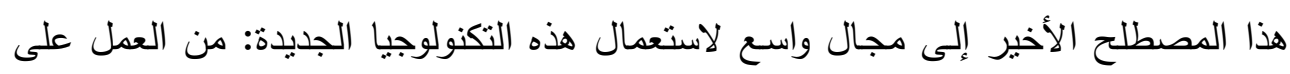
الحاسوب في قاعات التعليم، إلى التواصل عن بعد مـع برنامج دراسي كامل. وهو يتميز لاسئيل

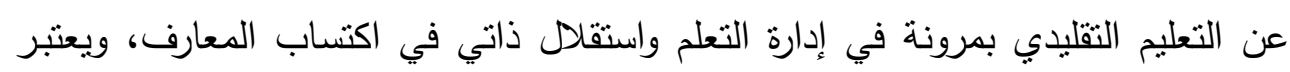

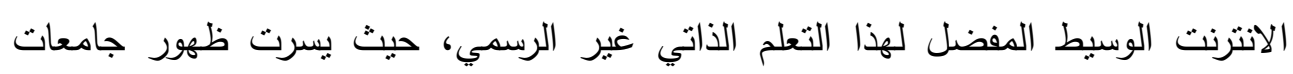

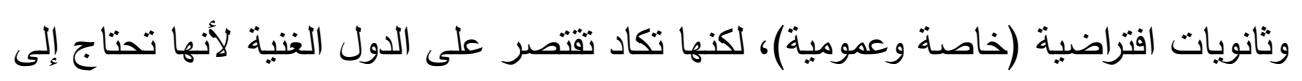

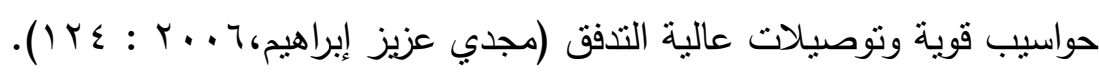

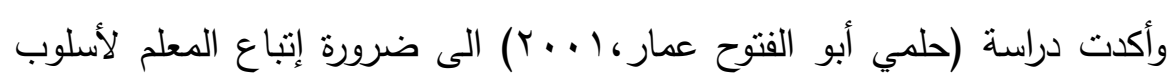
الأنظمة في التدريس بحيث يتم رسم مخطط لإستراتيجية الدرس تعمل فيه طرق التدريس

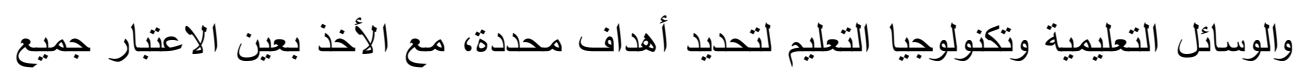

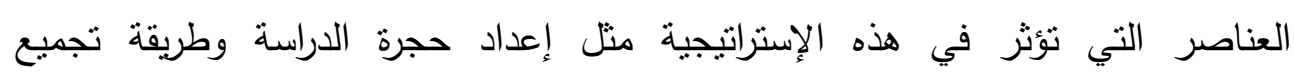
الأطفال.... الخ الخرئ

ان هذه التحديات الراهنة التي تواجه العملية التعليمية تفرض عليها تغييرا لفلسفتها وأدواتها، حتى تتتاسب آلياتها مع الآليات المطلوبة، وهذه الأخيرة لا تقتصر على لثى استخدام

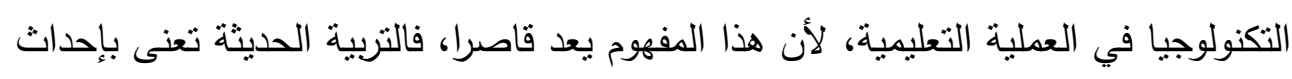

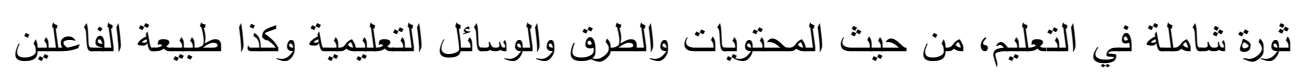

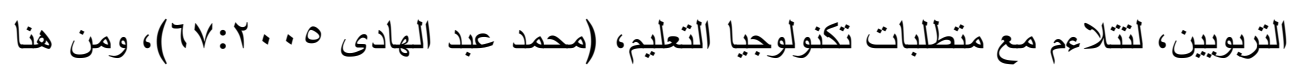


كان واجب التربية هو إعداد أجيال قادرة على التعامل مع ثقافة التكنولوجيا، وعلى مواجهة المشكلات التي يطرحها التقدم العلمي والتقافي الذي فرضته، وهذا بعني بلغة التربية مكافحة

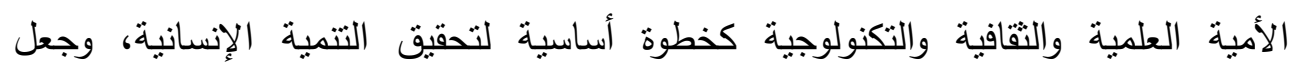
مخرجات التربية تتماشى ومتطلبات سوق العمل المتطورة هي الأخرى.

وقد نجحت تكنولوجيا المعلومات عن طريق الكمبيوتر في إعادة بناء التفكير

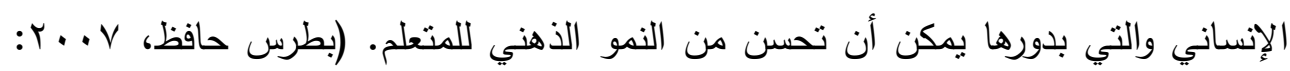

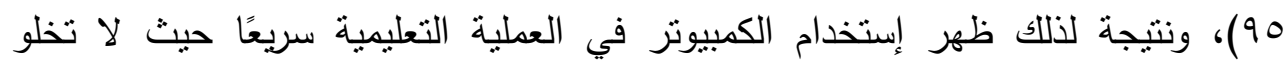
مدرسة أو روضة من جهاز كمبيوتز، ومع ذلك لم يوظف الكمبيوتر التوظيف الأمتل له له

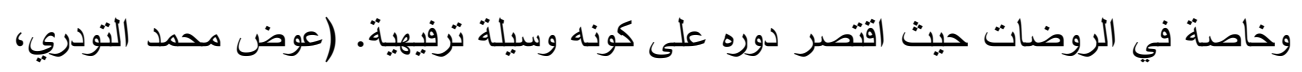

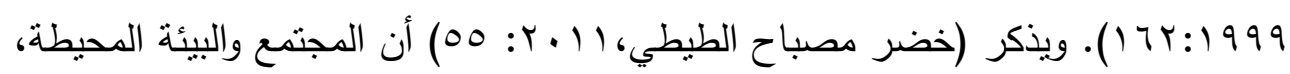
والمسئولين بالمؤسسة، والضرورات والتطلعات، والضغوطات الخارجية، جميعها تؤدي إلى إنى إحداث التغيير .

وهذا ما دعى البحث الحالى للتفكير فى محاولة تفعيل بنك المعرفة المصرى من

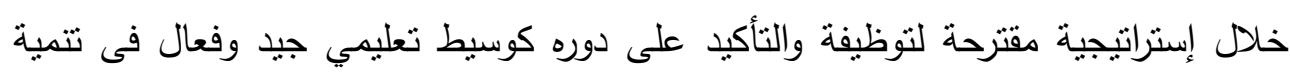
بعض المفاهيم العلمية لطفل الروضة، ومن خلال خبرة معلمات رياض الأطفال في تعليم

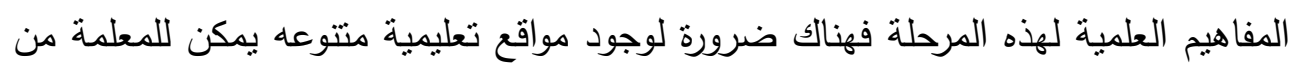
خلالها تبسيط بعض المفاهيم العلمية للطفل بطريقة شيقة.

\section{الاجراءات الميدانية للبحث: أولاً: منهج البحث:}

اتبعت الباحثة المنهج الوصفى التحليلى الذى يقوم على وصف الظواهر وتفسيرها

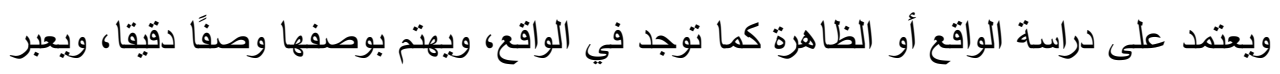
عنها تعبيرًا كيفيا، أو تعبيرا كميا ــ والمنهج الوصفى التحليلى يعد الأنسب لطبيعة البحث. 
تكونت عينة البحث من معلمات رياض الأطفال المتخصصات التى يعملن

بالروضات التجريبى والحكومى التابعين للمديريات التعليمية بالقاهرة التى تتضمن( إدارة تعليمية بمحافظة القاهرة، ( 20) إدارة تعليمية بمحافظة الجيزة، وتم أختبار عينة

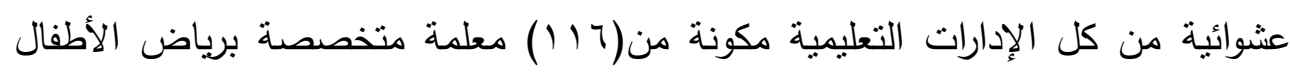

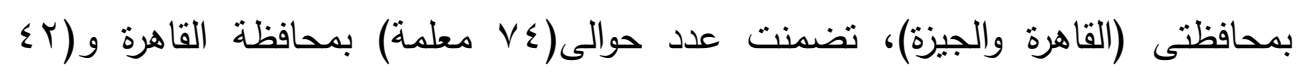
معلمة) بمحافظة الجيزة، ولديهن خبرة بالمجال. وفيما يلى جدول (1) بضم الئم الإدارات

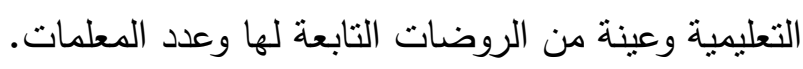

جدول( ) :عينة مجتمع الدراسة

\begin{tabular}{|c|c|c|c|}
\hline عدد المعلمات & اسم الروضة & الإدارة التعليمية & المحافظة \\
\hline 9 & -الثروق التجربيبة & \multirow[t]{5}{*}{ حلوان } & \multirow[t]{13}{*}{ 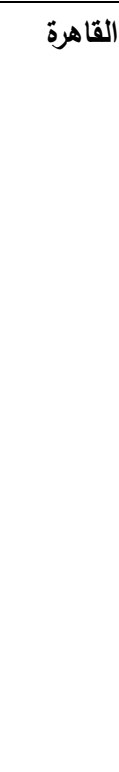 } \\
\hline 7 & - مصطفى كامل التجريية & & \\
\hline$\varepsilon$ & -المستقبل تجريبى متميز & & \\
\hline$r$ & - حمامات حلوان (رسمى عريى) & & \\
\hline$\varepsilon$ & -أحمد زويل (رسمى عريح) & & \\
\hline 1. & - سعد زغلول - تجريبى متميز & \multirow[t]{4}{*}{ المعصرة } & \\
\hline 9 & - م بيناير تجريبى & & \\
\hline$\varepsilon$ & - مصر الحرة رسمى -عربى & & \\
\hline$\wedge$ & - - ب يونيو تجريبى & & \\
\hline 0 & -الحلمية التجربية & \multirow{4}{*}{ والثقليفة } & \\
\hline 7 & - المقطم (رسمى عربى) & & \\
\hline 7 & - السيدة خديجة (رسمى عربى) & & \\
\hline V معلمة V & الإجمالى & & \\
\hline 9 & - مدرسة جأكتوير الرسمية & \multirow[t]{4}{*}{ إدارة أكتوبر } & \multirow[t]{6}{*}{ 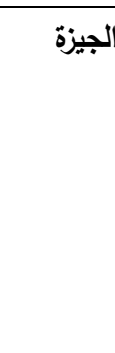 } \\
\hline 7 & - - مدرسة الحى السابع & & \\
\hline 7 & - - المدرسة الصنية & & \\
\hline $\mathrm{v}$ & - المدرسة الإلمانية & & \\
\hline$\varepsilon$ & - - سعد زغلول & \multirow[t]{2}{*}{ إدارة جنوب الجيزة } & \\
\hline 0 & - روضة صلاح سالم & & \\
\hline
\end{tabular}


المجلة العلمية لكلية رياض الاطفال - جامعة اسيوط

\begin{tabular}{|c|c|c|c|}
\hline عدد المعلمات & اسم الروضة & الإدارة التعليمية & المحافظة \\
\hline$\varepsilon$ & - عمرو بن العاص & & \\
\hline$\leq$ & - ابو بكر & & \\
\hline ب ع معلمة & الإجمالى & & \\
\hline
\end{tabular}

تجانس العينة من حيث المؤهل العلمى وسنوات الخبرة:

الجدول التالى يوضح العلاقة بين المؤهل العلمى وسنوات الخبرة بإختبار إيتا:

جدول (ץ): العلاقة بين المؤهل العلمى وسنوات الخبرة بإختبار إيتا

\begin{tabular}{|c|c|c|c|c|}
\hline الدلاية & إيتا & الإنحراف المعيارى & المتوسط & المجموعة \\
\hline غير دال إحصـائبا & $\because 1 v_{0}$ & 0.39 & r... & مستوى التعليم \\
\hline غبر دال إحصائبا & .0174 & 1.08 & T.T & سنوات الخبرة \\
\hline
\end{tabular}

يوضح الجدول السابق أن قيمة (إينا) غير دالة إحصائياً بالنسبة للمتغيرين فهنا نؤكد ان متغير مستوى التعليم وسنوات الخبرة مستقلان. ثالثاً : إعداد أدوات البحث :

1. إستمارة إسنطلاع راى معلمات رياض الأطفال عن توظيف بنك المعرفة فى الأنشطة العلمية r. أستبيان الوعى (ببنك المعرفة المصرى) لدى معلمات رياض الأطفال. r. أستراتيجية مقترحة لتوظيف بنك المعرفة فى الأنشطة العلمية لدى معلمات رياض الأطفال.

(جميع الأدوات السابقة من إعداد الباحثة) أولا: إستمارة إستطلاع لاى معلمات رياض الأطفال عن توظيف بنك المعرفة في الأنشطة العلمية: (ملحق رقم 1) 
تهدف الى التعرف على معلومات ومهارات المعلمة فى توظيف بنك المعرفة فى الأنشطة المختلفة بالروضة، ومدى مساهمة وزارة التربية والتعليم فى توفير ایى دورات تدربية تخص التدريب على بنك المعرفة.

ثانيا: أستيان الوعى (بينك المعرفة المصرى) لاى معلمات رياض الأطفال:(ملحق رقمبر) وترجع أهمية الأستبيان فى معرفة مدى وعى معلمات رياض بكيفية توظيف بنك

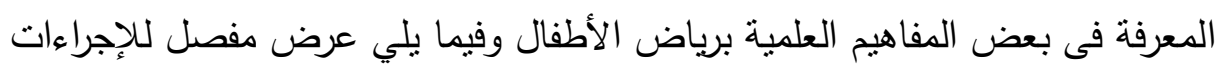

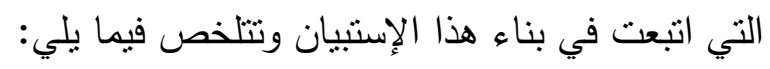
1- تحدبد أهداف الأستيـان:ويهدف الأستبيان إلى : ا.تحديد مدى وعى معلمات رياض الأطفال ببنك المعرفة المصرى . r. تحديد مدى توظيف المعلمات لبنك المعرفة المصرى فى تتمية بعض المفاهيم العلمية لطفل الروضة.

r- ثانبا: وصف الأستبيان: يتكون الأستبيان من ثلاث محاور رئيسية كل محور

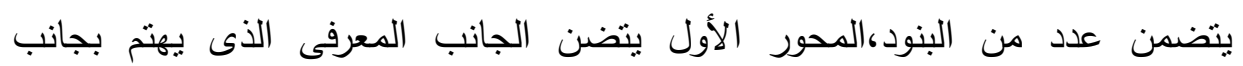

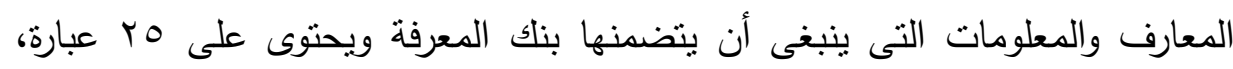

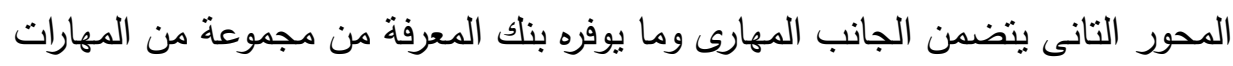

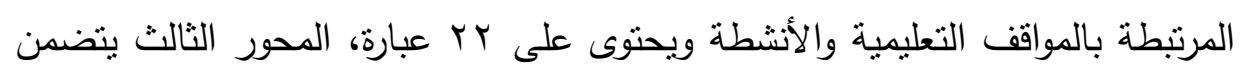
إستراتيجية تطبيق بنك المعرفة بالروضة وما يوفره بنك المعرفة من أنشطة وأساليب مرنبطة ببعض المفاهيم العلمية لطفل الروضة. r- :ضبط الأستبيان: وتتمل عملية ضبط المقياس على الخطوات التالية: أ- التأكد من صدق الأستيبان: للنأكد من صدق المقياس تم عرضه بعد تصميمه

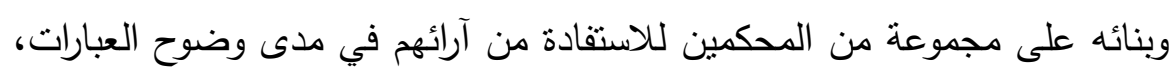

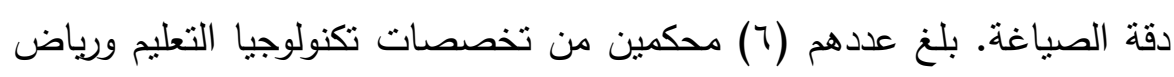
الأطفال، وذلك بهدف تحكيم الأداة وإبداء آرائهم حول صند الثن الأداة من حيث وضوح 
العبارات، ومدى ملاعمتها لقياس ما وضعت من أجله، ومدى انتمائها للمحاور التي

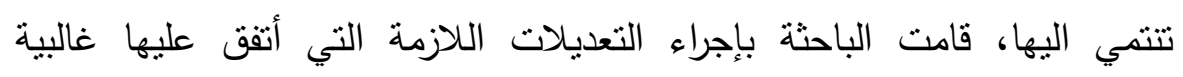

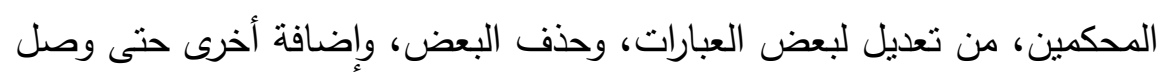

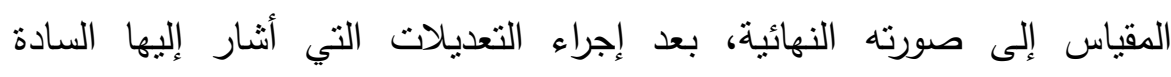

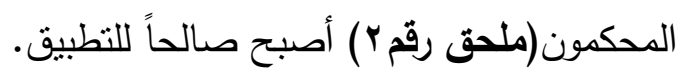

- صدق الاتساق الاخلي:

وقد جري التحقق من صدق الاتساق الداخلي للمقياس بحساب معامل ارتباط بيرسون بين متوسط كل محور والمتوسط الكلي للفقرات، وذللك بإستخدام البرنامج (spss)

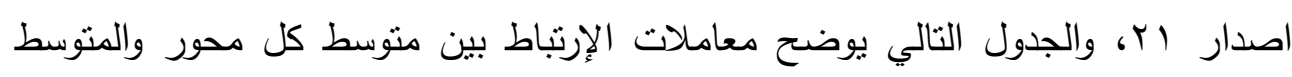
الكلي للفقرات : (اكلي

جدول رقم (ץ):يوضح معاملات الإرتباط بين متوسط كل محور والمتوسط الكلي للققرات

\begin{tabular}{|c|c|c|}
\hline قيمة الدلالة & معامل الارتباط & المحاور \\
\hline$\cdots \cdots$ &. $.190 * *$ & المحور الأول:الجاتب المعرفى \\
\hline$\cdots \cdots$ &. .А९ץ ** & المحور التانى : الجانب المهارى \\
\hline$\cdots \cdots$ &.$\vee V \vee V * *$ & بالروضة المحور الثالث : استراتيجية تطبيق بنك المعرفة \\
\hline
\end{tabular}

** Correlation is significant at 0.00 level $(2-$ tailed $)$

ومن نتائج الجدول السابق نجد ان جميع معاملات ارتباط بيرسون معاملات ثنات

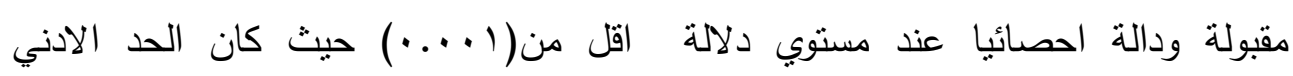

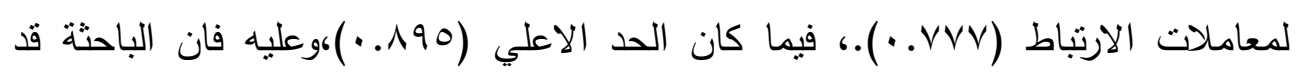
تأكدت من صدق الاتساق الداخلي للمقياس و وبذلك اصبح صان لإنح للتطبيق علي عينة الدراسة.

ب- التأكد من ثبات الأستبيان : لقياس مدي ثبات اداة الدراسة (الأستبيان) أستخدمت الباحثة (معادلة الفا كرونباخ) للتاكد من ثبات اداة الدراسة علي علئي عينة 
استطلاعية مكونة من(·r) وقد نم إستبعادها من العينة الكلية، والجدول رقم (ع) يوضح معاملات ثبات اداة الدراسة.

جدول رقم (؛):ثبات محاور الأستبيان

\begin{tabular}{|c|c|c|c|}
\hline الصدق & ثبات المحور & عدد العبارات & 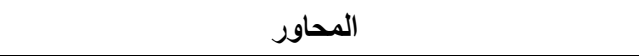 \\
\hline. .90 &. .91 & ro & المحور الأول:الجاتب المعرفى \\
\hline. .94 & .94 & rr & المحور التانى : الجانب المهارى \\
\hline. $.9 \mathrm{~V}$ & .90 & ri & المحور الثالث : استراتيجية تطبيق بنك المعرفة بالروضة \\
\hline. $.9 \mathrm{v}$ &. .90 & 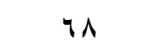 & الثبات العام للإستبانة \\
\hline
\end{tabular}

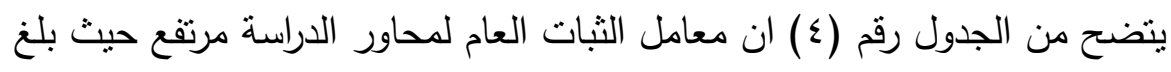

(90 . ·) لإجمالي فقرات المقياس الثمانية والستين، فيما تراوح ثبات المحاور ما بين (19 (9. •)

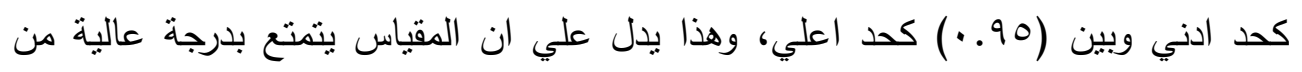

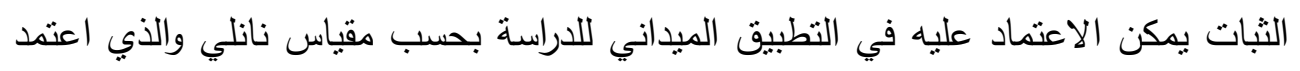

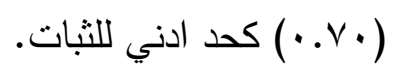

ثالثا: أستراتيجية مقترحة لتوظيف بتك المعرفة فى الأنشطة العلمية لاى معلمات رياض

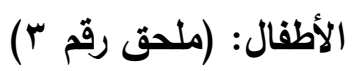

الإستراتيجية المقترحة: يعرفها البحث إجرائيا بأنها عبارة عن مقترح ينظم توظيف بنك المعرفة المصرى لتتمية بعض المفاهيم العلمية لطفل الروضة وذلك لتحقيق الأهداف التعليمية بمجال العلوم، و يقدم من خلال بيئة تعليم تفاعلية تتضمن خطوات اجرائية محددة وقد تتاول البحث هذا الجزء بالتفصيل (ملحق بم). تفسير نتائج البحث ومناقشتهيا: للإجابة عن تساؤلات البحث استخدمت الباحثة برنامج spss للإجابة عن السؤال الأول والذي ينص ما الجواتب المعرفية التى تحتاجها المعلمات

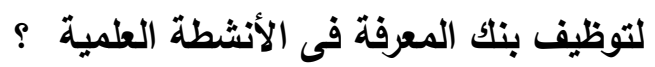




\section{المجلة العلمية لكلية رياض الاطفال - جامعة اسيوط}

قامت الباحثة بتطبيق استبيان يتضمن الجوانب المعرفية التى تحتاجها المعلمات

لتوظيف بنك المعرفة فى الأنشطة العلمية وذلك من خلال الرجوع الى الأدبيات والدراسات السابقة تم إعداد القائمة وتحكيمها من أساتذة المناهج وتكنولوجيا التعليم ورياض الأنس لأطفال لإبداء الرأى حول هذه الجوانب ومدى مناسبتها لتوظيف بنك المعرفة (ملحق رقم ؟)، وكانت

نتائج عبارات المحور الاول كما هو موضح بجدول رقم(0)

جدول (•) نتائج عبارات المحور الاول

\begin{tabular}{|c|c|c|c|c|c|c|c|}
\hline النتيجة & الانحراف & المتوسط & موافق & موافق الى حد ما & غير موافق & المقياس & عبارات المحور الاول (الجاتب المعرفى) \\
\hline \multirow{2}{*}{ موافق } & \multirow{2}{*}{0.47} & \multirow{2}{*}{2.7} & 84 & 31 & 1 & تكرار & \multirow{2}{*}{ بوضر الانثطة العلمية } \\
\hline & & & 72.4 & 26.7 & 0.9 & 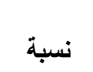 & \\
\hline \multirow{2}{*}{ موافق } & \multirow{2}{*}{0.6} & \multirow{2}{*}{2.6} & 76 & 33 & 7 & 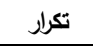 & \multirow{2}{*}{ والنشاط في حياة الطفل اللعب } \\
\hline & & & 65.5 & 28.4 & 6 & 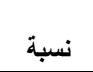 & \\
\hline \multirow[b]{2}{*}{ موافق } & \multirow[b]{2}{*}{0.56} & \multirow[b]{2}{*}{2.6} & 74 & 38 & 4 & تكرار & \multirow{2}{*}{ بوفر معلومات المعائط المتعددة واهمية } \\
\hline & & & 63.8 & 32.8 & 3.4 & نسبة & \\
\hline \multirow{2}{*}{ موافق } & \multirow{2}{*}{0.66} & \multirow{2}{*}{2.5} & 64 & 41 & 11 & 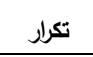 & \multirow{2}{*}{ زيادة التفاعل بين المعرفة علي المعلمات والاطفال } \\
\hline & & & 55.2 & 35.3 & 9.5 & نسبة & \\
\hline \multirow{2}{*}{ موافق } & \multirow{2}{*}{0.62} & \multirow{2}{*}{2.3} & 46 & 60 & 10 & 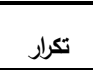 & \multirow{2}{*}{ التعاون بين الروضة معلومات عن كيفية } \\
\hline & & & 39.7 & 51.7 & 8.6 & 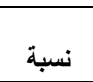 & \\
\hline \multirow{2}{*}{ موافق } & \multirow[b]{2}{*}{0.56} & \multirow[b]{2}{*}{2.5} & 66 & 46 & 4 & 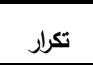 & \multirow{2}{*}{ يساهم في خلق بيئة } \\
\hline & & & 56.9 & 39.7 & 3.4 & نسبة & \\
\hline \multirow{2}{*}{ موافق } & \multirow{2}{*}{0.52} & \multirow{2}{*}{2.5} & 70 & 44 & 2 & 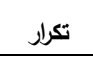 & \multirow{2}{*}{ يطاعات الروضة المعلمة داخل } \\
\hline & & & 60.3 & 37.9 & 1.7 & نسبة & \\
\hline \multirow{2}{*}{ موافق } & \multirow{2}{*}{0.51} & \multirow{2}{*}{2.6} & 78 & 36 & 2 & تكرار & \multirow{2}{*}{ يساعد علي التنوع في $\quad$ مصادر المعلومات و المعرفة } \\
\hline & & & 67.2 & 31 & 1.7 & نسبة & \\
\hline \multirow[b]{2}{*}{ موافق } & \multirow[b]{2}{*}{0.5} & \multirow[b]{2}{*}{2.6} & 82 & 32 & 2 & 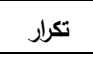 & يساعد علي زيادة ثقافة المعلمة \\
\hline & & & 70.7 & 27.6 & 1.7 & نسبة & من منعدة علال دخولها علي مواقع \\
\hline & & & 68 & 43 & 5 & تكرار & يساعد علي تنمية الجوانب \\
\hline موافق & 0.58 & 2.5 & 58.6 & 37.1 & 4.3 & نسبة & لمعلمة الروضية والمهارية والوجدانية \\
\hline
\end{tabular}




\begin{tabular}{|c|c|c|c|c|c|c|c|}
\hline النتيجة & المعيارى & المتوسط & موافق & موافق الى حد ما & غير موافق & المقياس & عبارات المحور الاول (الجانب المعرفى) \\
\hline \multirow[t]{2}{*}{ 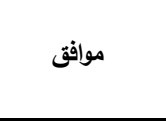 } & \multirow[t]{2}{*}{0.53} & \multirow[t]{2}{*}{2.6} & 78 & 35 & 3 & تكرار & \multirow{2}{*}{ في دخل علي اتاحة الفرصة للمعلمات } \\
\hline & & & 67.2 & 30.2 & 2.6 & نسبة & \\
\hline \multirow[b]{2}{*}{ 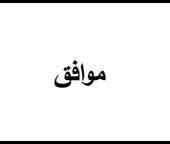 } & \multirow[b]{2}{*}{0.55} & \multirow[b]{2}{*}{2.6} & 77 & 35 & 4 & 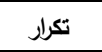 & \multirow{2}{*}{ العصول علي المطلومات للمفاهيم } \\
\hline & & & 66.4 & 30.2 & 3.4 & نسبة & \\
\hline \multirow{2}{*}{ 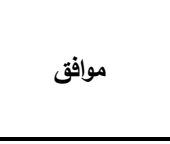 } & \multirow{2}{*}{0.61} & \multirow{2}{*}{2.5} & 66 & 43 & 7 & 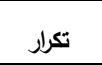 & \multirow{2}{*}{ الاطفال علي تطوير مرحلة رياض } \\
\hline & & & 56.9 & 37.1 & 6 & 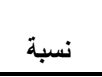 & \\
\hline \multirow{2}{*}{ 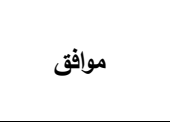 } & \multirow{2}{*}{0.6} & \multirow{2}{*}{2.5} & 70 & 39 & 7 & تكرار & \multirow{2}{*}{ يساعد علي تبادل الخبرات بين } \\
\hline & & & 60.3 & 33.6 & 6 & 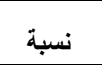 & \\
\hline \multirow[b]{2}{*}{ 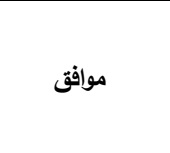 } & \multirow[b]{2}{*}{0.62} & \multirow[b]{2}{*}{2.5} & 65 & 43 & 8 & 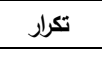 & \multirow{2}{*}{ 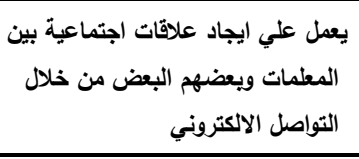 } \\
\hline & & & 56 & 37.1 & 6.9 & ن & \\
\hline \multirow[b]{2}{*}{ 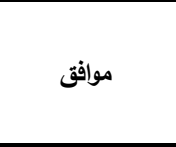 } & \multirow[b]{2}{*}{0.58} & \multirow[b]{2}{*}{2.5} & 60 & 51 & 5 & 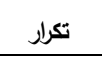 & \multirow{2}{*}{ الاستفادة من الزمن } \\
\hline & & & 51.7 & 44 & 4.3 & نسبة & \\
\hline \multirow{2}{*}{ موافق الى حد ما } & \multirow{2}{*}{0.58} & \multirow{2}{*}{2.3} & 46 & 63 & 7 & 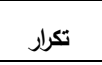 & \multirow{2}{*}{ ليتيح التواصل الاكتروني للاطفال } \\
\hline & & & 39.7 & 54.3 & 6 & نسبة & \\
\hline \multirow[t]{2}{*}{ 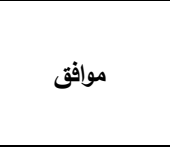 } & \multirow[t]{2}{*}{0.62} & \multirow[t]{2}{*}{2.4} & 52 & 55 & 9 & 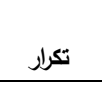 & \multirow{2}{*}{ يمكن تخزين بيانات ومطومات الليزي } \\
\hline & & & 44.8 & 47.4 & 7.8 & نسبة & \\
\hline 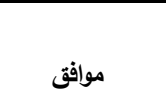 & 0.54 & 2.5 & 67 & 46 & 3 & تكرار & يعمل بنك المعرفة علي تنمية \\
\hline & & & 57.8 & 39.7 & 2.6 & نسبة & 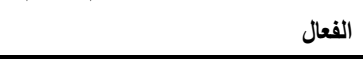 \\
\hline فماف & 0.5 & 2.4 & 59 & 51 & 6 & 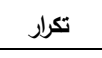 & يتيح الفرصة لمساعدة المعلمة \\
\hline مواتى & 0.59 & 2.4 & 50.9 & 44 & 5.2 & نسبة & لابتكار انثطة جديدة \\
\hline & & & 86 & 27 & 3 & 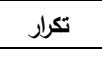 & اؤيد فكرة الزام الوزارة بضرورة تدريب \\
\hline 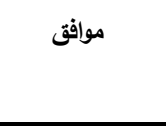 & 0.5 & 2.7 & 74.1 & 23.3 & 2.6 & نسبة & منه برياض الاطفال \\
\hline موافق الى حـ ما & 0.7 & 2.3 & 51 & 49 & 16 & تكرار & يسهل تطبيق بنك المعرفة داخل \\
\hline & & & 44 & 42.2 & 13.8 & نسبة & قاعة النثاط \\
\hline موافق الى حد ما ما & 0.77 & 2.2 & 49 & 42 & 25 & 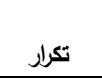 & شاركت في برنامج تدريبي عن كيفية \\
\hline
\end{tabular}


المجلة العلمية لكلية رياض الاطفال - جامعة اسيوط

\begin{tabular}{|c|c|c|c|c|c|c|c|}
\hline النتيجة & الانحراف المعيارى & 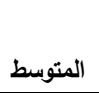 & موافق & موافق الى حد ما & غير موافق & 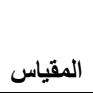 & عبارات المحور الاول (الجانب المعرفى) \\
\hline & & & 42.2 & 36.2 & 21.6 & نسبة & تطبيق بنك المعرفة برياض الاطفال \\
\hline \multirow{2}{*}{ موافق الى حـ ما } & \multirow[t]{2}{*}{0.65} & \multirow[t]{2}{*}{2.3} & 49 & 55 & 12 & 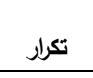 & \multirow{2}{*}{ لتي لدي خلفية علمية عن المواد التعليمية ا } \\
\hline & & & 42.2 & 47.4 & 10.3 & 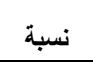 & \\
\hline \multirow{2}{*}{ موافق } & \multirow{2}{*}{0.58} & \multirow{2}{*}{2.4} & 57 & 54 & 5 & 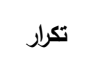 & \multirow{2}{*}{ 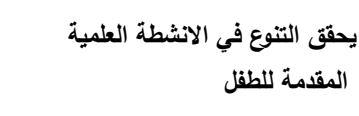 } \\
\hline & & & 49.1 & 46.6 & 3.4 & نسبة & \\
\hline \multirow{2}{*}{ 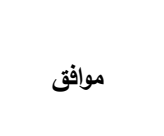 } & \multirow{2}{*}{0.31} & \multirow{2}{*}{2.5} & 1640 & 1092 & 168 & 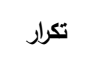 & \multirow{2}{*}{ نتيجة المحور الاول } \\
\hline & & & 0.57 & 0.38 & 0.05 & 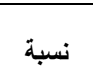 & \\
\hline
\end{tabular}

بعد دراسة الجدول السابق لنتائج المحور الاول (الجانب المعرفي) نجد انه حصل

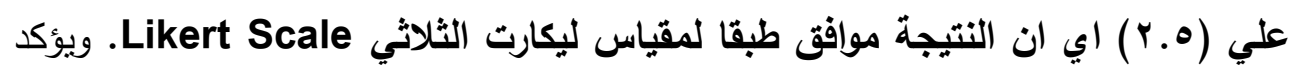

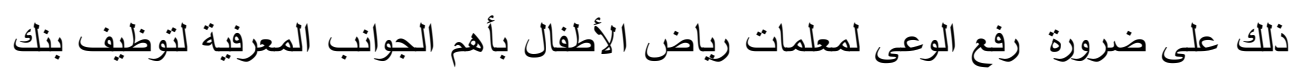

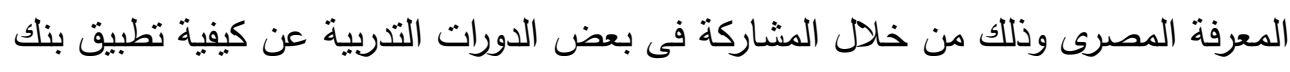
المعرفة برياض الاطفال لكى يكون لديها خلفية علمية عن المواد التعليمية التي يتضمنها بنك المعرفة ليسهل تطبيق بنك المعرفة داخل قاعة النشاط.

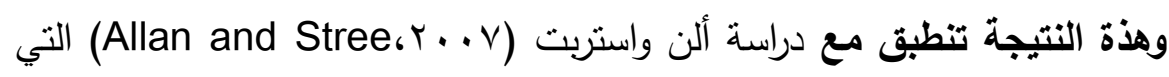
استهدفت التعرف علي اثز استخدام المعرفة القائمة علي أستخدام الإنترنت في تدريب دئن

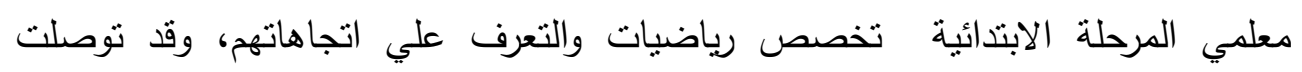

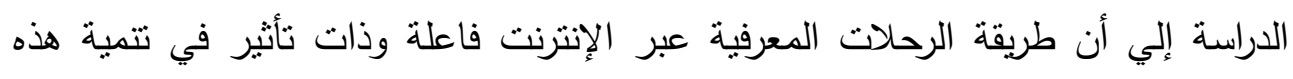

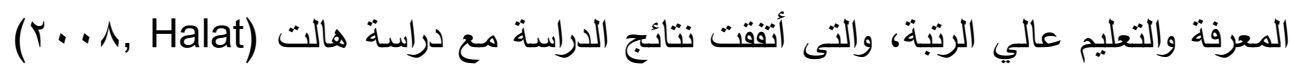

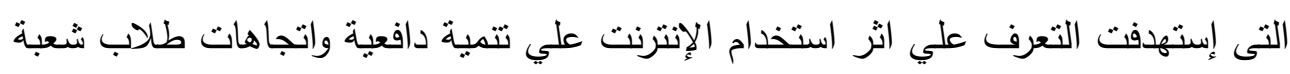

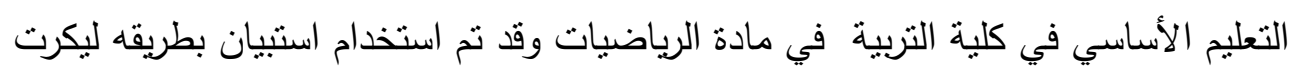

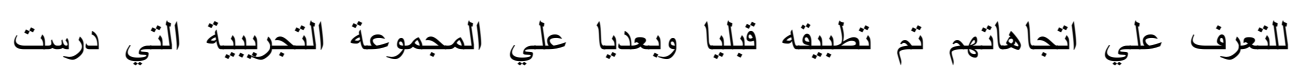
بالإنترنت والمجموعة الضابطة، وتوصلت الدراسة إلي وجود فروق ذات دلالة فئة إحصائية في تكوين اتجاهات ايجابية نحو مقرر الرياضيات بين المجموعة التجريبية والضابطة لصالح

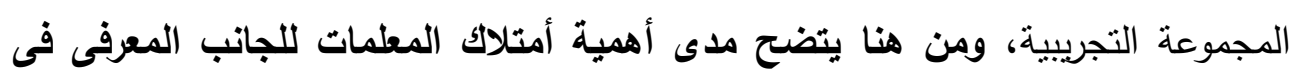


إستخدام كل ما هو جديد بمجال رياض الأطفال خاصا فيما يتعلق بالتكنولوجيا الحديثة ومواقع التعلم التابعة لوزارة التربية والتعليم. وللإجابة عن السؤال الثانى والذي ينص على: ما المهارات التى تحتاجها المعلمات لتوظيف بنك المعرفة فى الأنشطة العلمية ؟

قامت الباحثة بتطبيق استبيان يتضمن بعض المهارات التى تحتاجها المعلمات لتوظيف بنك المعرفة فى الأنشطة العلمية وذلك من خلال الرجوع الى الأدبيات والدراسات السابقة تم إعداد القائمة وتحكيمها من أساتذة المناهج وتكنولوجيا التعليم ورياض الأنيه لأطفال (ملحق رقم r) الإبداء الرأى حول هذه الجوانب ومدى مناسبتها لتوظيف بنك المعرفة.وكانت نتائج عبارات المحور الثانى كما هو موضح بجدول رقم (؟) جدول (7) نتائج عبارات المحور الثانى

\begin{tabular}{|c|c|c|c|c|c|c|c|}
\hline النتيجة & الانحراف & المتوسط & موافق & موافق الى حد ما & غير موافق & | المقياس & 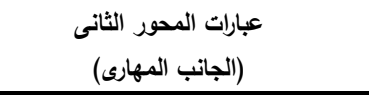 \\
\hline \multirow{2}{*}{ مد مافق الي } & \multirow[t]{2}{*}{0.62} & \multirow[t]{2}{*}{2.3} & 48 & 58 & 10 & تكرار & \multirow{2}{*}{ يوفرينك المعرفة تنظيم الموقف } \\
\hline & & & 41.4 & 50 & 8.6 & نسبة & \\
\hline \multirow{2}{*}{ مد مافق الي } & \multirow{2}{*}{0.71} & \multirow{2}{*}{2.2} & 44 & 52 & 20 & تكرار & \multirow{2}{*}{ للبرنامج برياض مساعدتي للتخطيط السنوي } \\
\hline & & & 37.9 & 44.8 & 17.2 & نسبة & \\
\hline \multirow{2}{*}{ موافق } & \multirow{2}{*}{0.62} & \multirow{2}{*}{2.37} & 52 & 55 & 9 & تكرار & \multirow{2}{*}{ اليومية في في التخطيط للانثطة العلوم } \\
\hline & & & 44.8 & 47.4 & 7.8 & نسبة & \\
\hline \multirow[b]{2}{*}{ موافق } & \multirow[b]{2}{*}{0.68} & \multirow[b]{2}{*}{2.4} & 61 & 42 & 13 & تكرار & \multirow{2}{*}{ والتي يخطط لها لئي الي اهداف معرفية الاهداف التعليمية } \\
\hline & & & 52.6 & 36.2 & 11.2 & نسبة & \\
\hline \multirow{2}{*}{ مد مافق الي } & \multirow{2}{*}{0.69} & \multirow{2}{*}{2.3} & 52 & 49 & 15 & تكرار & \multirow{2}{*}{ التي يخطط لها بصياغة سلوكية الاهداف التعليمية } \\
\hline & & & 44.8 & 42.2 & 12.9 & نسبة & \\
\hline \multirow[b]{2}{*}{ موافق } & \multirow[b]{2}{*}{0.57} & \multirow[b]{2}{*}{2.38} & 50 & 61 & 5 & تكرار & \multirow{2}{*}{ يُبكاهم في توظيف الفيديوهات التعليمية } \\
\hline & & & 43.1 & 52.6 & 4.3 & نسبة & \\
\hline \multirow{2}{*}{ موافق } & \multirow{2}{*}{0.51} & \multirow{2}{*}{2.5} & 66 & 49 & 1 & تكرار & \multirow{2}{*}{ توفير الانترنت مناسبة للتعلم } \\
\hline & & & 56.9 & 42.2 & 0.9 & نسبة & \\
\hline موافق & 0.51 & 2.5 & 69 & 46 & 1 & تكرار & حفز الاطفال للمشاركة \\
\hline
\end{tabular}


المجلة العلمية لكلية رياض الاطفال - جامعة اسيوط

\begin{tabular}{|c|c|c|c|c|c|c|c|}
\hline النتيجة & الانحراف & المتوسط & موافق & موافق الى حد ما & غير موافق & المقياس الم & $\begin{array}{c}\text { عبارات المحور الثانى المهارى) } \\
\text { (الجاتب }\end{array}$ \\
\hline & & & 59.5 & 39.7 & 0.9 & نسبة & في النشاط العلمي \\
\hline \multirow{2}{*}{ 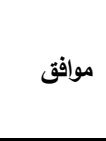 } & \multirow{2}{*}{0.56} & \multirow{2}{*}{2.4} & 59 & 53 & 4 & تكرار & استخدام طرق واجراءات تثير \\
\hline & & & 50.9 & 45.7 & 3.4 & نسبة & النثشاط بشكل تفاعلي أقيام بعرص \\
\hline \multirow{2}{*}{ 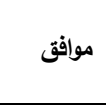 } & \multirow{2}{*}{0.56} & \multirow{2}{*}{2.5} & 68 & 44 & 4 & تكرار & تنظيم الانثطة العلمية في العرض \\
\hline & & & 58.6 & 37.9 & 3.4 & نسبة & من السهل الي الصعب \\
\hline \multirow[b]{2}{*}{ 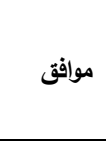 } & \multirow[b]{2}{*}{0.57} & \multirow[b]{2}{*}{2.38} & 50 & 61 & 5 & تكرار & يتوفر في الانشطة العلمية المقدمة \\
\hline & & & 43.1 & 52.5 & 4.3 & نسبة & العمية بين الحقائق والمفاهيم والمبادى \\
\hline \multirow[t]{2}{*}{ 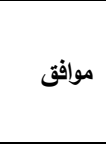 } & \multirow[t]{2}{*}{0.62} & \multirow[t]{2}{*}{2.4} & 58 & 50 & 8 & تكرار - ت & يوفر اساليب لتقويم النشاط \\
\hline & & & 50 & 43.1 & 6.9 & نسبة & \\
\hline \multirow[t]{2}{*}{ 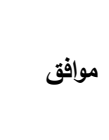 } & \multirow[t]{2}{*}{0.58} & \multirow[t]{2}{*}{2.5} & 64 & 47 & 5 & 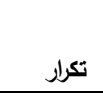 & \multirow[t]{2}{*}{ علي التجديد والابتكار بما يناسب اطفالها } \\
\hline & & & 55.2 & 40.5 & 4.3 & نسبة & \\
\hline \multirow[t]{2}{*}{ 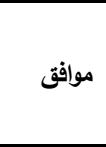 } & \multirow[t]{2}{*}{0.61} & \multirow[t]{2}{*}{2.5} & 65 & 44 & 7 & 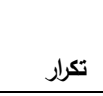 & \multirow[t]{2}{*}{ 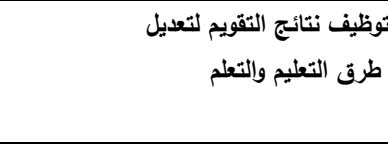 } \\
\hline & & & 56 & 37.9 & 6 & نسبة & \\
\hline \multirow{2}{*}{ مد مافق الي } & \multirow[t]{2}{*}{0.63} & \multirow[t]{2}{*}{2.3} & 43 & 61 & 12 & تكرار & \multirow[t]{2}{*}{ مواطن الضعف نتائج التقويم لتصديد الاطفال } \\
\hline & & & 37.1 & 52.6 & 10.3 & نسبة & \\
\hline \multirow{2}{*}{ مد مافق الي } & \multirow{2}{*}{0.67} & \multirow{2}{*}{2.3} & 52 & 51 & 13 & تكرار & الاستفادة من نتائج التقويم في \\
\hline & & & 44.8 & 44 & 11.2 & 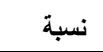 & تناسب مستوي الطفل \\
\hline \multirow{2}{*}{ 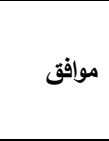 } & \multirow{2}{*}{0.59} & \multirow{2}{*}{2.4} & 55 & 55 & 6 & تكرار & يعزز التواصل ومشاركة الافكار \\
\hline & & & 47.4 & 47.4 & 5.2 & 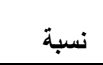 & الوسائط الاجتماعية التريجي \\
\hline \multirow{2}{*}{ 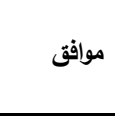 } & 0.6 & 2.4 & 54 & 55 & 7 & 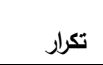 & ان يتوفر بالمواد التعليمية \\
\hline & & & 46.6 & 47.4 & 6 & نسبة & ممارسات تعزيز الاداء \\
\hline | & 0.53 & 25 & 65 & 49 & 2 & تكرار - ت ت ت & تتوع في مصادر المعرفة التي \\
\hline لموفئ & 0.00 & 2.0 & 56 & 42.2 & 1.7 & نسبة & تعين المعلمة علي تنفيذ النثاط العلمي \\
\hline مصمقفت & 0.58 & 24 & 60 & 51 & 5 & تكرار & توفر نماذج متنوعة من اساليب \\
\hline مؤاتق & 0.50 & 2.4 & 51.7 & 44 & 4.3 & نسبة & التعليم والتعلم تمكنها من الاختيار المناسب \\
\hline & & & 48 & 55 & 13 & تكرار & الاستفادة من الزيارات الميدانية \\
\hline | حد ماتى الم & 0.66 & 2.3 & 41.4 & 47.4 & 11.2 & نسبة & الافتراضية التي تنظمها \\
\hline موافق & 0.62 & 2.35 & 50 & 57 & 9 & تكرار & توافر موارد رقمية تفاعلية وتثثل \\
\hline
\end{tabular}




\begin{tabular}{l|r|r|r|r|r|r|r}
\hline نتئnnn \\
\hline
\end{tabular}

- بعد دراسة الجدول السابق لنتائج المحور الثاني (الجانب المهاري) نجد انه حصل علي (Y (Y) اي انه موافق طبقا لمقياس ليكارت الثلاثي Likert Scale. الجدول السابق بأنه لا بشترط أن بتوفر ببنك المعرفة تتظيم الموقف التعليمي في ضواء الاهداف المحدودة أو المساهمه فى عملية التخطيط ولكن أوضحوا أهمية نوظيف نتائج

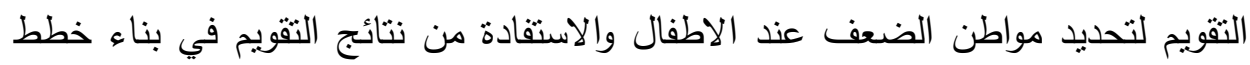

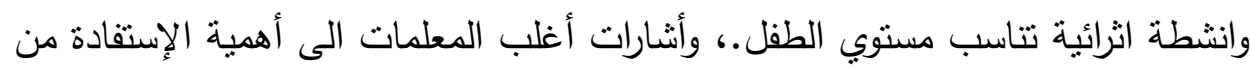

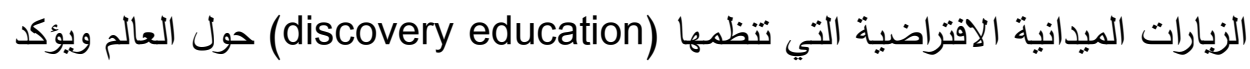

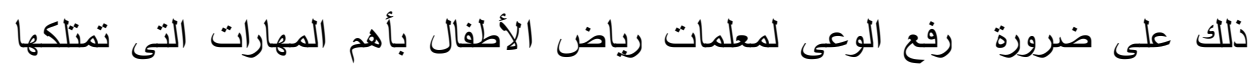
لتوظيف بنك المعرفة المصرى.

وهذة النتيجة تنطبق مع دراسة أنشار ديلون (Dillon,S, ...v) على أن هناك(T) ولاية) في أمريكا قد قامت بنطبيق نظام المدارس التي تعتمد على الانترنت

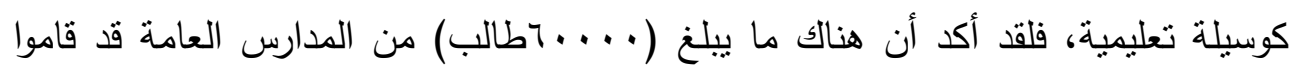
بالتسجيل في دورات العلوم الالكترونية المتمنلة في المعامل الافتراضية، وقال أساتذة العلوم أن استخدام المحاكاة الالكترونية من المكن أن يعطي نتائج جيدة للغاية حيث أنها تستخدم

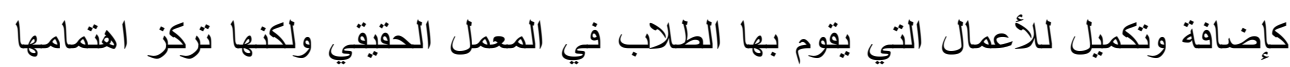
على تدعيم المتعلمين الذين ليس لديهم أي خبرة عملية في كيفية التعامل مع المعامل لئل

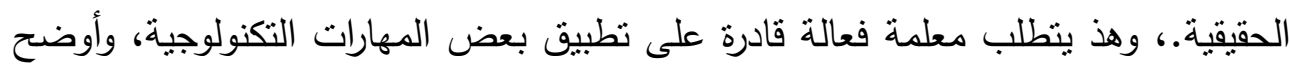

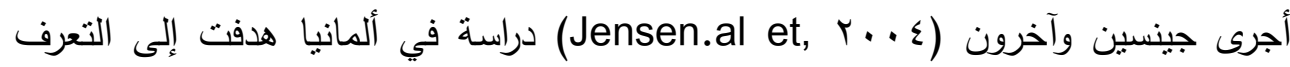
على أثز استخدام المعمل الافتراضي على تحصيل الطلاب في مجال العلوم الطبيعية والهندية، وأظهرت نتائج هذه الدراسة عدم وجود فرق ذو دلالة إحصائية ما بين أفراد الفئ

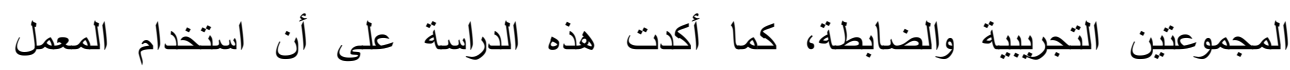


الافتراضي شجع المستخدمين على التقليل من أخطأ التعليم وهذا من شأنه أن يحسن من ونان

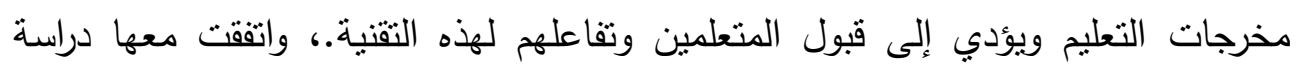

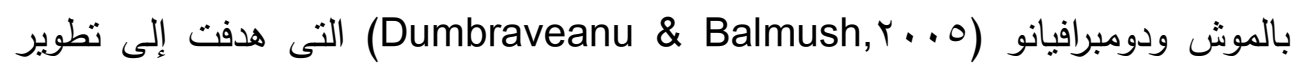

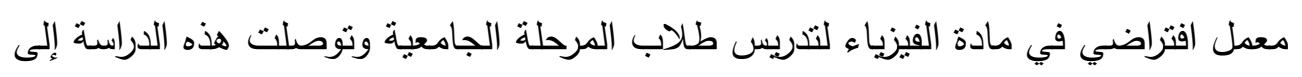

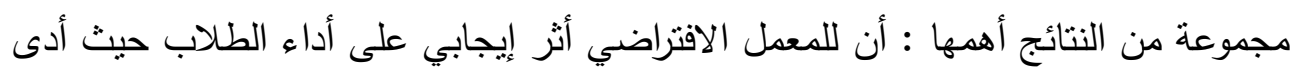

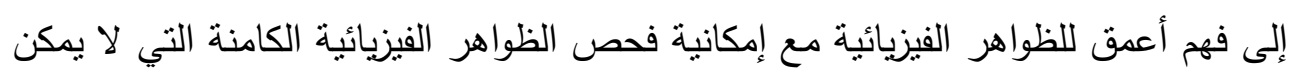
التعرف عليها في المعمل الحقيقي وبالتالي تحسن استيعابهم للظواهر الفيزيائية.

ومن هذا العرض السابق نؤكد على أهمية توظيف الفيديوهات التعليمية والواقع

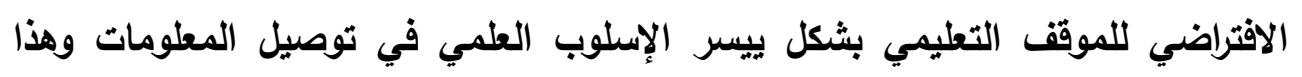
يتوفر بينك المعرفة المصرى. وللإجابة عن السؤال الثالث والذي ينص على: لئل

ما الإستراتيجية المقترحة لتوظيف بنك المعرفة فى الأنثطة العلمية برياض الأطفال؟ قامت الباحثة بتطبيق استيان يتضمن إستراتيجية تطبيق بناك المعرفة بالروضة ومدى توفر مجموعة من الإنثطة والإساليب المرتبطة ببعض المفاهيم العلية لطفل الروضة بنك المعرفة وخاصة بعض الإستراتيجيات الحديثة فى تطبيق وتعلم الدفاهيم العلمية

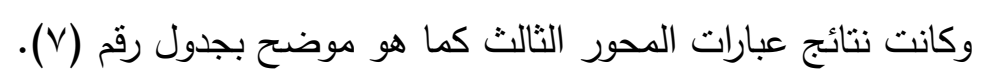


جدول (V):نتائج عبارات المحور الثالث كما هو موضح بجدول (V).

\begin{tabular}{|c|c|c|c|c|c|c|c|}
\hline النتيجة & 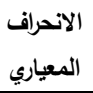 & المتوسط & موافق & موافق & 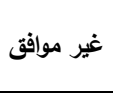 & المقياس & عبارات المحور الثالث (استراتيجية التطبيق) \\
\hline \multirow{2}{*}{ 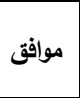 } & \multirow{2}{*}{0.57} & \multirow{2}{*}{2.6} & 81 & 29 & 6 & تكرار & \multirow{2}{*}{ سيساعدني بنك المعرفة علي تطبيق الانشطة العلمية } \\
\hline & & & 69.8 & 25 & 5.2 & نسبة & \\
\hline \multirow{2}{*}{ 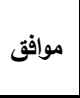 } & \multirow{2}{*}{0.49} & \multirow{2}{*}{2.7} & 89 & 24 & 3 & تكرار & \multirow{2}{*}{ لابد من توفر جهاز كمبيوتر في كل قاعة بالروضة } \\
\hline & & & 76.7 & 20.7 & 2.6 & نسبة & \\
\hline \multirow{2}{*}{ موافق } & \multirow{2}{*}{0.54} & \multirow{2}{*}{2.5} & 70 & 43 & 3 & تكرار & \multirow{2}{*}{ تقديم الروضة الذدمات المساندة مع توفير بيئة تعليمية الكترونية } \\
\hline & & & 60.3 & 37.1 & 2.6 & نسبة & \\
\hline \multirow{2}{*}{ موافق } & \multirow{2}{*}{0.54} & \multirow{2}{*}{2.6} & 73 & 40 & 3 & 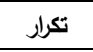 & \multirow{2}{*}{ تعصاون اولياء امور الاطفال مع الروضة بصفتهم معينين } \\
\hline & & & 62.9 & 34.5 & 2.6 & نسبة & \\
\hline \multirow{2}{*}{ 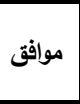 } & \multirow{2}{*}{0.46} & \multirow{2}{*}{2.6} & 80 & 35 & 1 & 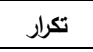 & \multirow{2}{*}{ 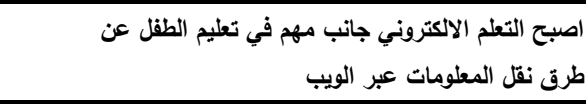 } \\
\hline & & & 69 & 30.2 & 0.9 & نسبة & \\
\hline \multirow{2}{*}{ 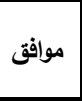 } & \multirow{2}{*}{0.49} & \multirow{2}{*}{2.7} & 91 & 23 & 2 & تكرار & \multirow{2}{*}{ اشعر بالمتعة عند توظيفي للفبديوهات التعليمية بمجال العلوم } \\
\hline & & & 68.4 & 19.8 & 1.7 & نسبة & \\
\hline \multirow[b]{2}{*}{ 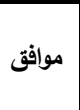 } & \multirow[b]{2}{*}{0.57} & \multirow{2}{*}{2.6} & 88 & 25 & 3 & تكرار & \multirow{2}{*}{ اؤيد تبادل المعلومات بالانترنت تحت اشراف وزارة التربية والتعليم } \\
\hline & & & 75.9 & 21.6 & 2.6 & نسبة & \\
\hline لمبرافت & 056 & 26 & 76 & 35 & 5 & 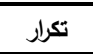 & احب معرفة كيف يتم انتاج الفيديوهات التعليمية التعليمية \\
\hline مواتى & 0.50 & 2.0 & 65.5 & 30.2 & 4.3 & نسبة & من خلال الصور التعليمية \\
\hline & 046 & 7 & 81 & 30 & 5 & تكرار & \\
\hline موافق & 0.46 & 2.7 & 69.8 & 25.9 & 4.3 & نسبة & يههني تعلم كيف يتم نعل المعلومات من والي بتك المعروه \\
\hline & 053 & 26 & 90 & 24 & 2 & تكرار & احب معرفة اي جليد عن تكنولوجيا المعلومات \\
\hline موافق & 0.53 & 2.6 & 77.6 & 20.7 & 1.7 & نسبة & خاصة فيما يتعلق برياض الاطفال \\
\hline & 055 & 26 & 77 & 36 & 3 & 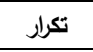 & يعد بنك المعرفة اداة مهمة للحصول علي \\
\hline مواقف & 0.55 & 2.0 & 66.4 & 31 & 2.6 & نسبة & المفاهيم العلمية المناسبة لطقل الروضة \\
\hline & & & 74 & 38 & 4 & تكرار & يتضمن علي مجموعة متنوعة من انواع \\
\hline 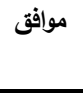 & 0.58 & 2.5 & 63.8 & 32.8 & 3.4 & نسبة & 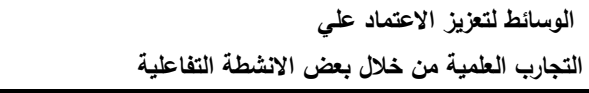 \\
\hline مصرافة & 0.59 & 25 & 69 & 42 & 5 & 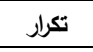 & 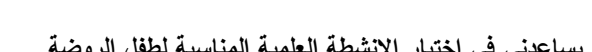 \\
\hline 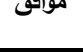 & 0.59 & 2.5 & 59.5 & 36.2 & 4.3 & نسبة & اليساسدي سي احيلر الاسطه العميه ا \\
\hline مهوافة & 0.59 & 2.5 & 67 & 43 & 6 & 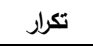 & الاستفادة من الانشطة العلمة ياستخدام الهاقع الإفتراضر \\
\hline موافق & 0.39 & 2.5 & 57.8 & 37.1 & 5.2 & نسبة & الاسفاده من الاستطه العلميه بإسحدام الواقع الاعتراصي \\
\hline & 0.53 & 26 & 76 & 37 & 3 & 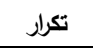 & الالتحاق بدورات تدريبية تريوية خاصة بطرق \\
\hline مواقف & 0.53 & 2.0 & 65.5 & 31.9 & 2.6 & نسبة & توظيف بنك المعرفة في مجال العلوم \\
\hline & 0.6 & 25 & 72 & 37 & 7 & 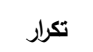 & توفر جهة العمل فرص الدراسة والاطلاع للاستفادة \\
\hline موافق & 0.6 & 2.5 & 62.1 & 31.9 & 6 & نسبة & من تطبيق بنك المعرفة بالروضة \\
\hline 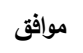 & 0.59 & 2.5 & 68 & 42 & 6 & 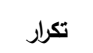 & الالمام بالطرق والاساليب المتنوعة التي تخدم \\
\hline
\end{tabular}


المجلة العلمية لكلية رياض الاطفال - جامعة اسيوط

\begin{tabular}{|c|c|c|c|c|c|c|c|}
\hline 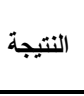 & 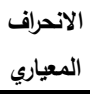 & 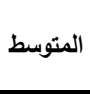 & موافق & مالي حد مافق & غير موافق & 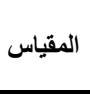 & عبارات الدحور الثالث (استراتيجية التطبيق) \\
\hline & & & 58.6 & 36.2 & 5.2 & نسبة & توظيف بنك المعرفة بالانثطة العلمية \\
\hline \multirow{2}{*}{ | موافق } & \multirow{2}{*}{0.66} & \multirow{2}{*}{2.5} & 72 & 33 & 11 & تكراد & \multirow{2}{*}{ الخاصة بتطبيق بنك المعرفة بالروضي الاهداف والقواعد والطرق والمباديء } \\
\hline & & & 62.1 & 28.4 & 9.5 & نسبة & \\
\hline \multirow{2}{*}{ | موافق } & \multirow{2}{*}{0.63} & \multirow{2}{*}{2.4} & 56 & 51 & 9 & تكرار & \multirow{2}{*}{ تجري مسابقات بين معلمات ومشرفات رياض اطفال في مجال انتاج } \\
\hline & & & 48.3 & 44 & 7.8 & 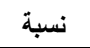 & \\
\hline \multirow{2}{*}{ موافق } & \multirow{2}{*}{0.53} & \multirow{2}{*}{2.6} & 75 & 38 & 3 & 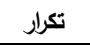 & \multirow{2}{*}{ توظيف الانثطة العلمية التفاعلية لاثارة انتباه الطفل } \\
\hline & & & 64.7 & 32.8 & 2.6 & نسبة & \\
\hline \multirow{2}{*}{ | موافق } & \multirow{2}{*}{0.5} & \multirow{2}{*}{2.6} & 80 & 34 & 2 & 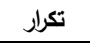 & \multirow{2}{*}{ التوفر الوسائل التعليمية المعينة وتوظيفها لتحقيق } \\
\hline & & & 69 & 29.3 & 1.7 & نسبة & \\
\hline \multirow{2}{*}{ | موافق } & \multirow{2}{*}{$\mathbf{0 . 3 3}$} & \multirow{2}{*}{2.6} & 1605 & 739 & 92 & تكرار & \multirow{2}{*}{ نتيجة المحور الثاثث } \\
\hline & & & 0.66 & 0.3 & 0.03 & نسبة & \\
\hline
\end{tabular}

- بعد دراسة الجدول السابق لنتائج المحورالثالث (إستراتيجة التطبيق) نجد انه حصل علي (Y.Y.7) اي انه موافق طبقا لمقياس ليكارت الثلاثي Likert Scale. وأوضحت نتائج الجدول السابق بتأكيد المعلمات على أن بنك المعرفة سيساعدهاعلي نطبيق الأنشطة

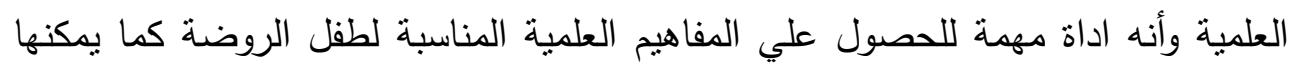
الإستفادة منه فى الأنشطة العلمية بإستخدام الواقع الافتراضي وهذا يترتب علية التحاق

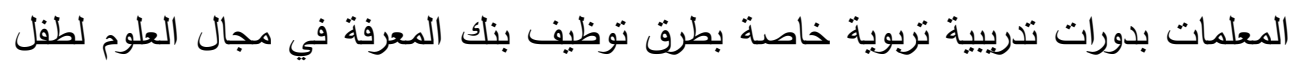
الروضة. ومن الإستراتيجيات الحديثة التى تساعد المعلمة على التجديد فى عرض بلى المفاهيم العلمية كأستراتيجية SOS) Spotlight on Strategies) هي استراتيجيات تعليمية إبداعية معتمدة على الأبحاث، وُضِعت للمعلمين بواسطة المعلمين. وتتضمن استراتيجيات التدريس البسيطة تلك وسائط رقمية بأساليب فعالة، وعملية وذات معنى.على سبيل المثال

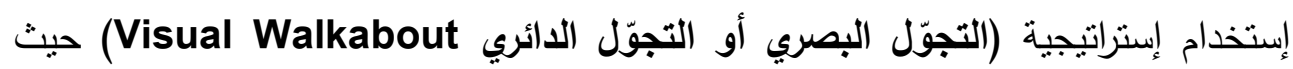
تستعرض هذه الاستراتيجية مفهومًا مجردًا مثل المجتمع أو الهواء باعتباره مادة من خلال

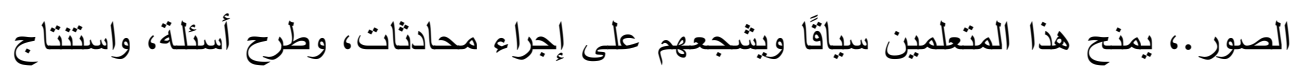
معلومات حول ما يشاهدونه، ويوكد ذلك على ضرورة رفع الوعى لمعلمات رياض الأطفال بالإستفادة من الإستراتيجية المقترحة لتوظيف بنك المعرفة المصرى. 
وهذا ما أكدتة بعض الدراسات السابقة مثل دراسة كنج (King,2003) التى

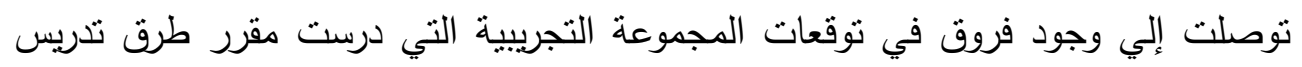

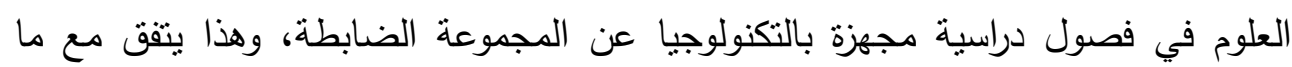

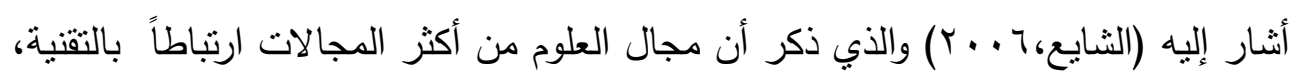

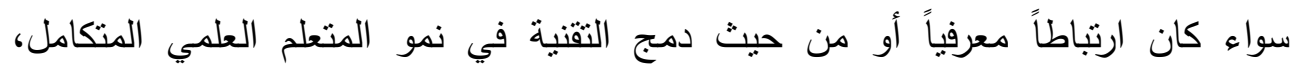
ويضيف أن العديد من التربويين يرون أهمية دمج تقنية المعلومات والاتصال في تعليم العلوم ويتفق ذلك على ما نوصلت الية نتائج البحث فى أهمية تحديد أستراتيجية مقترحة لتوظيف بنك المعرفه المصرى فى تتمية بعض المفاهيم العلمية لطفل الروضة. وتوصل البحث الى النتائج التالية :

بعد التحليل للمحاور الثنلاثة تحليلا كيفيا نستتنج وجود نسبة انخفاض في مستوى وعي المعلمات بإستخدام بنك المعرفة في الانشطة العلمية، وقد يمكن إرجاع هذه النتيجة إلى قصور ناتج عن عدم إلمام معلمات رياض الأطفال بالجوانب التكنولوجية الحديثة وكيفية توظيفها، إلى جانب عدم وضوح بعض المعلومات عن بنك المعرفة وكيفية توظيفة لتتمية

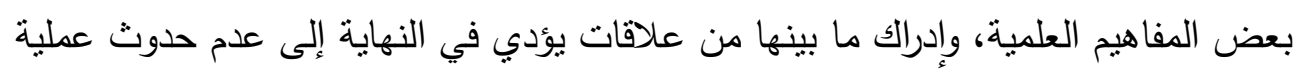
الاحتواء لكل ما هو جديد بالمجال الذى يلعب دوراً مهماً في البناء المعرفي للمعلمة، والتي فئي

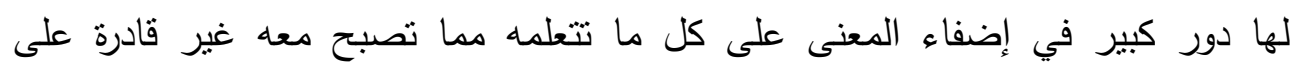
الاستفادة مما لديها من خبرات في بنائها المعرفي.

ومن خلال ذلك يمكنتا الأخذ بطرح فكرة بنك المعرفة كحل أساسي لتطوير المستوي

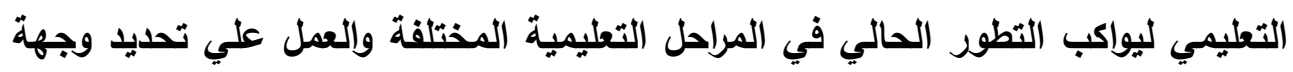
الجيل القادم نحو مجتمع ناجح فعال. توصياث البحث :

1- نشر الوعى بأهمية توظيف بنك المعرفة فى الأنشطة العلمية.

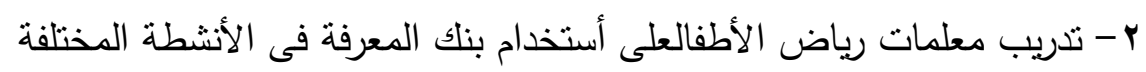
وخاصا الأنشطة العلمية. 


\section{بحوث ودراسات مقترحة :}

1 - برنامج لتتمية مهارات معلمات رياض الأطفال لتطبيق بنك المعرفى المصرى فى

$$
\text { تتمية بعض المفاهيم الرياضية لطفل الروضة. }
$$

r- دراسة تقويمية لمواقع الإنترنت التعليمية عن مدى مناسبتها فى تتمية بعض المفاهيم لطفل الروضة.

r- دراسة تحليلية لمحتوى بنك المعرفة المصرى والإستفادة من تطبيق البرامج التفاعلية بمرحلة رياض الأطفال. 


\section{مراجع}

\section{أولاً : المراجع العربية :}

1. إبراهيم بدران، حبيش علي(999) (199). التحديات العلمية التي نواجه الأمة الإسلامية وسبل

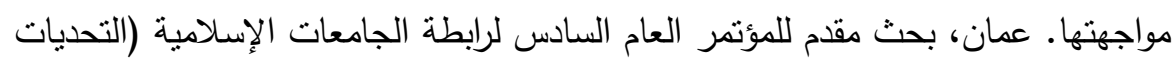

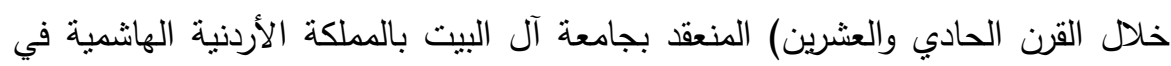

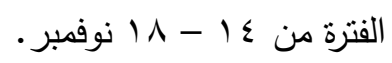

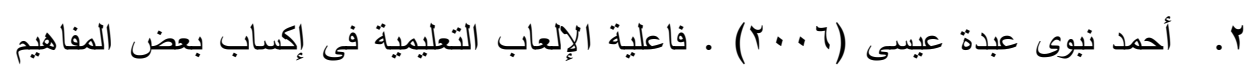

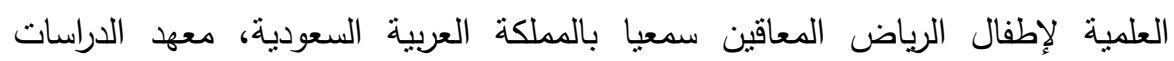
التربوية، جامعة القاهرة.

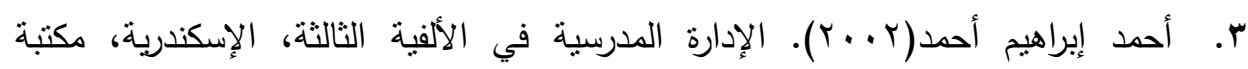
المعارف الحديثة.

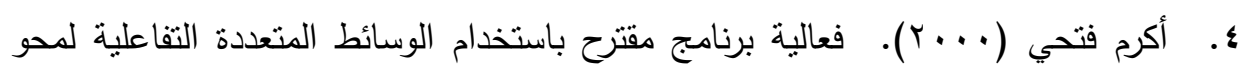

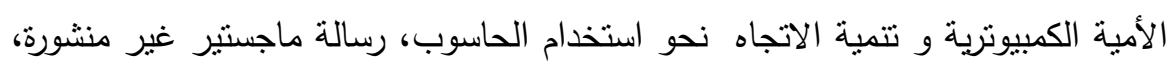
كلية التربية،جامعة جنوب الوادي.

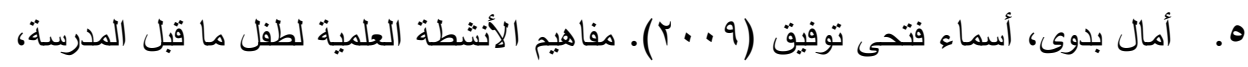

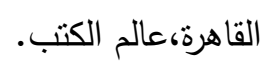

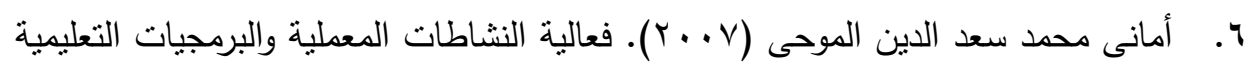

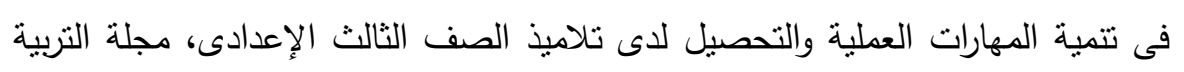
العلمية، الجمعية المصرية للتربية العلمية.

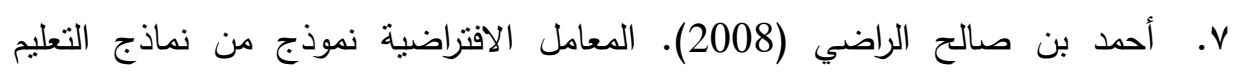

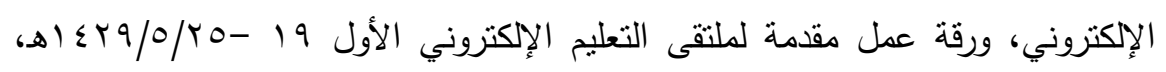

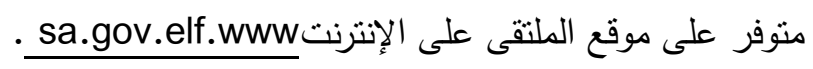
^. خضر مصباح الطبطي (1) (1). إدارة التغيير التحديات والإستراتيجيات للمدراء

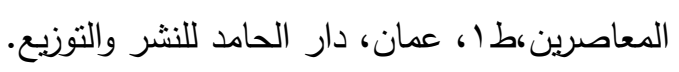

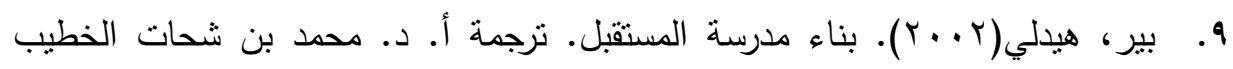

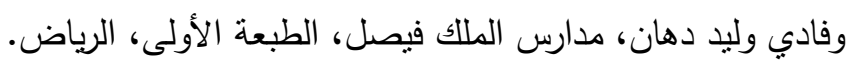




\section{المجلة العلمية لكلية رياض الاطفال - جامعة اسيوط}

• 1 بطرس حافظ (Y IV). تتمية المفاهيم العلمية والرياضية لطفل الروضة، عمان،

$$
\text { الأردن، دار المسيرة. }
$$

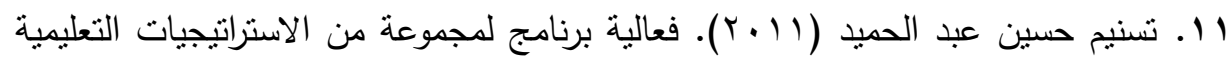
قي تتمية بعض المفاهيم التكنولوجية لدى طفل الروضة، رسالة ماجستير غير منشورة، كلية رياض الأطفال، جامعة القاهرة. r ا ـ جوزال عبد الرحيم أحمد، ووفاء محمد سلامة (0 . . ب). تتمية المفاهيم والمهارات العلمية لطفل الروضة، القاهرة، عالم الكتب. ب ا. ـ حسين بشير محمود( ( . . ץ). المدخل المنظومى فى تعلم المفاهيم، القاهرة، عالم الكتب.

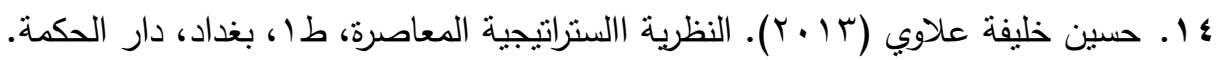
ه 1 ـ حنان حسن على خليل (^ . . ץ). تصميم ونشر مقرر إلكتروني فى تكنولوجيا التعليم فى ضوء معايير جودة التعليم الإلكتروني لتتمية الجوانب المعرفية والأدائية لدى طلاب كلية التربية، رسالة ماجستير ، كلية التربية، جامعة المنصورة.

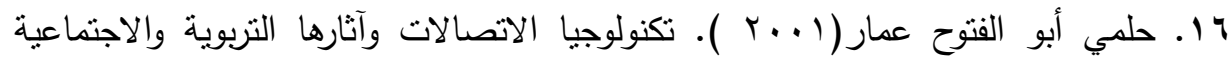
دراسة ميدانية بمملكة البحرين المؤتمر السادس عشر للحاسب والتعليم بالمملكة العربية

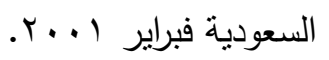

V V ا. رزق علي أحمد محمد (T . . (Y). تصميم موقع ويب تعليمي وأثزه علي تتمية بعض المهارات الأساسية في صيانة الكمبيوتر لاي طلاب كلية التربية النوعية ؛رسالة ماجستير غير منشورة، كلية التربية النوعية جامعة المنيا. ^ ا. زينب أسعد محفوظ يسري (ع ( • ץ). برنامج مقترح لتتمية الثقافة السياحية لدى طفل ما قبل المدرسة باستخدام الوسائط المتعددة في ضوء الاتجاهات العالمية الحديثة، رسالة دكتوراه، معهد الدراسات التربوية، جامعة القاهرة.

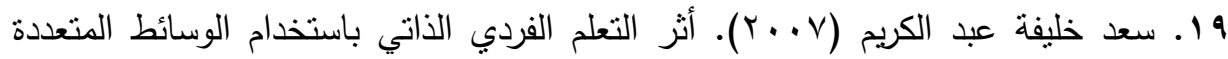
المتطورة والحقائب التعليمية في زيادة التحصيل لدي طلاب الأحياء بالفرقة الثانية بكلية التربية بسلطنة عمان. دراسة تجريبية، مجلة كلية التربية : جامعة أسيوط، عدد (،مجلة . . V V (IV) • r. سمير شريف والحوري، نصر حمدان (997 (1). مناهج اللغة العربية وطرائق تدريسها. الطبعة الأولى، اليمن: منشورات وزارة التربية والتعليم. 


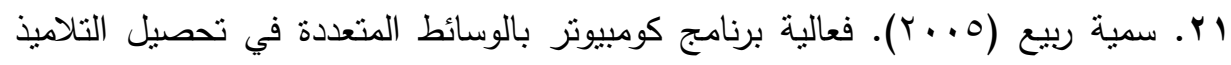
المعاقين عقلياً (القابلين للتعلم) لبعض مفاهيم العلوم والتربية الصحية في المملكة العربية

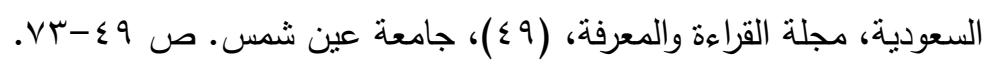

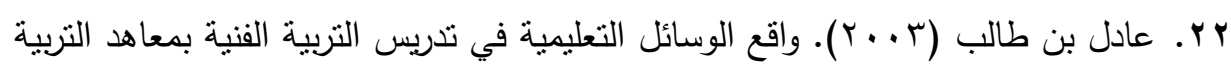

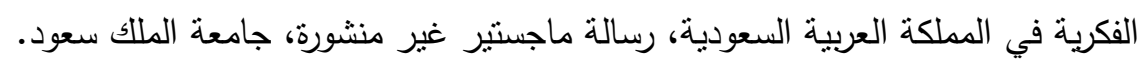

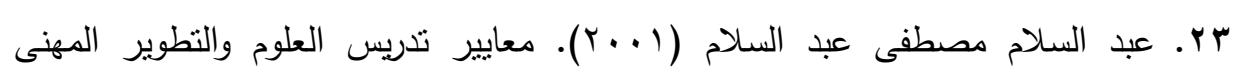

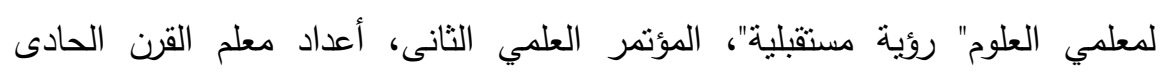
والعشرين، الجمعية المصرية للتربية العلمية.

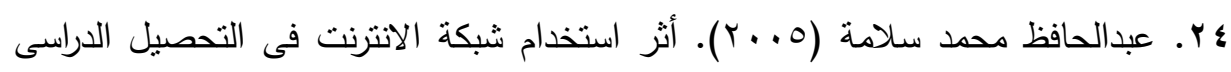

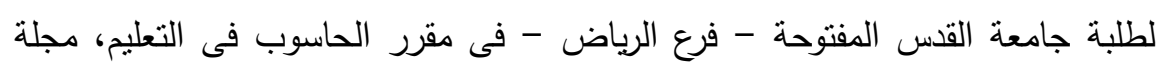

$$
\text { العلوم التربوية مجلد(؟) عدد( (1). }
$$

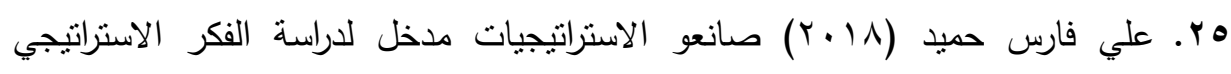
العالمي، العراق، دار الرافدين للطباعة.

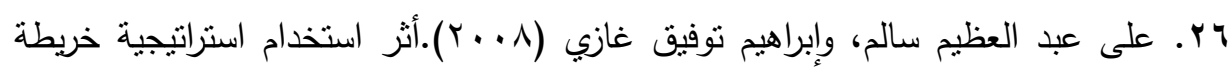

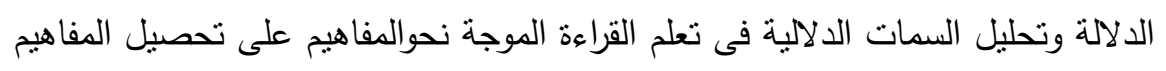

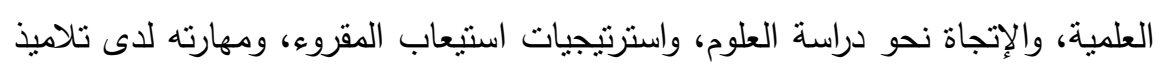
الصف الثانى الإعدادى، مجلة التربية العلمية. الجمعية المصرية.

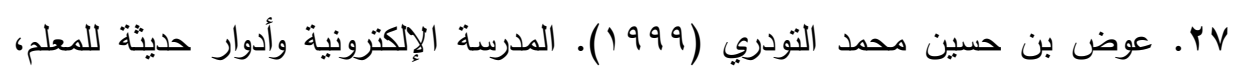

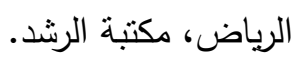

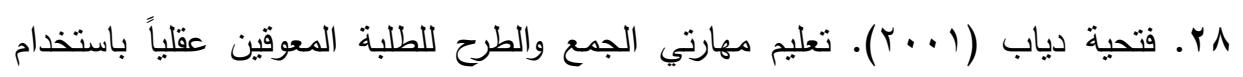
الحاسوب، رسالة ماجستير غير منشورة، الجامعة الأردنية.

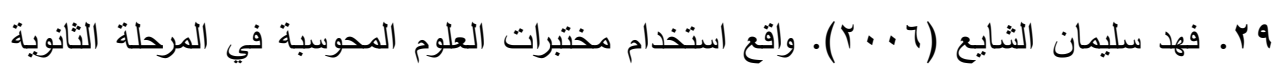

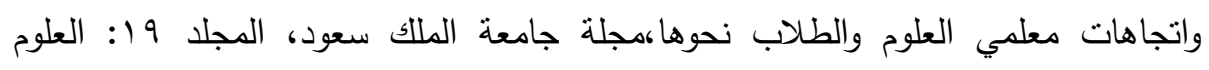
التربوية والدراسات الإسلامية، النشر العلمي والمطابع جامعة الملك سعود، الرياض.

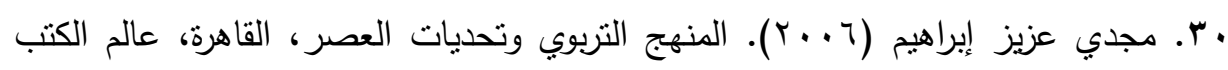

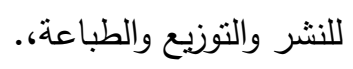

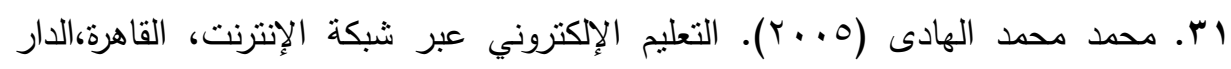
المصرية اللبنانية. 


\section{المجلة العلمية لكلية رياض الاطفال - جامعة اسيوط}

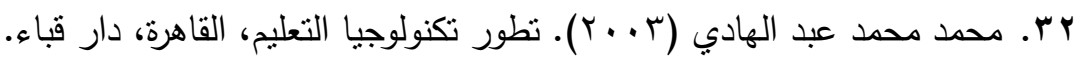

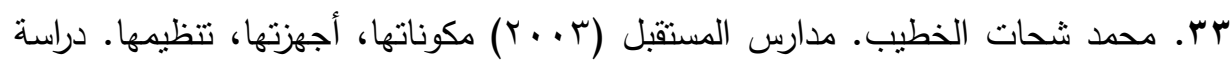

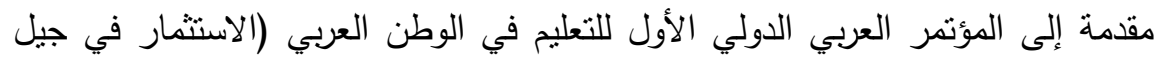

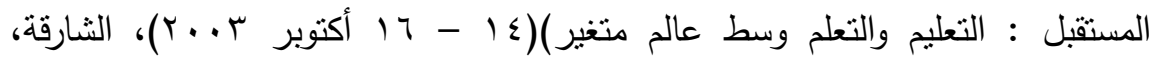

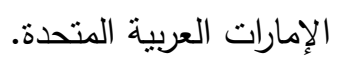

؛ ז. محمد عبد الله الصوفي، وقاسم عبد الغني(1997). أهم التحديات المستقبلية الني ستواجه أمتتا ودور التربية في حلها، بيروت، مؤسسة الرسالة.

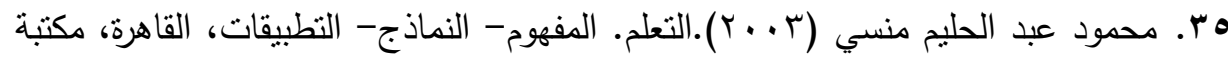
الأنجلو المصرية.

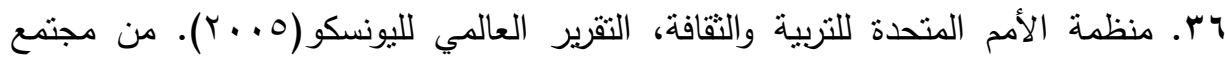

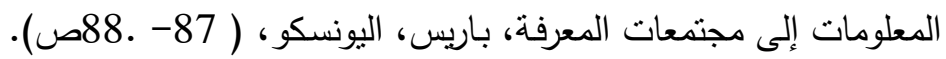

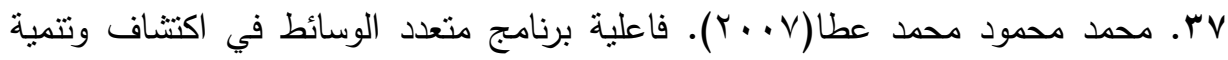
بعض مجالات الذكاءات المتعددة لدي طفل الروضة، رسالة دكتوراه، جامعة القاهرة، كلية

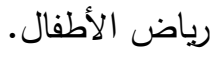

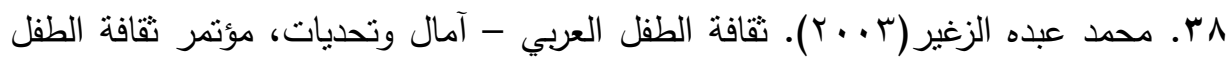

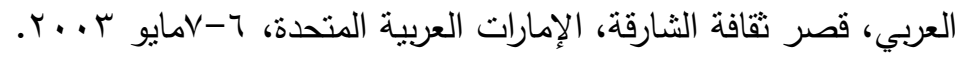

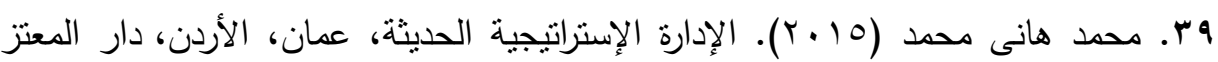
للنشر والتوزيع. • ـ . محمد صابر سليم (2002). الجديد فى ندريس العلوم، كلية التربية، جامعة عين شمس. ب. اءـ. محمد نصحى ابراهيم (10 • r). إستراتيجيات تطوير التعليم، دار الثروق للنشر ، القاهرة.

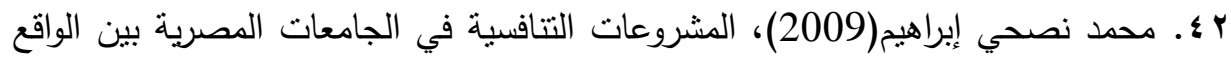

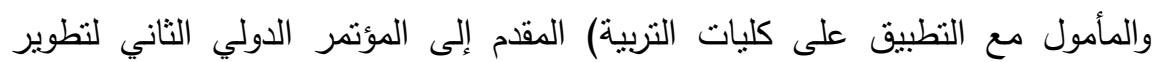

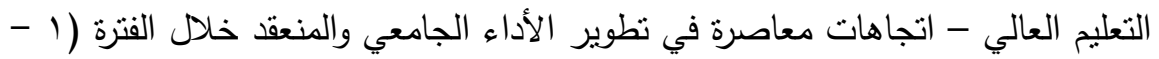

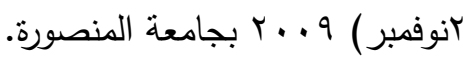

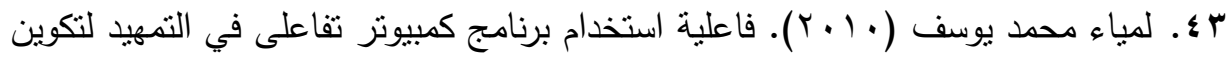
مفهوم الإحتفاظ لدى طفل الروضة، كلية رياض الاطفال، جامعة القاهرة، رسالة

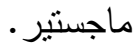




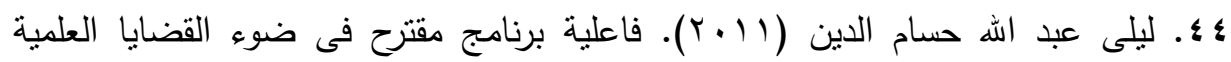

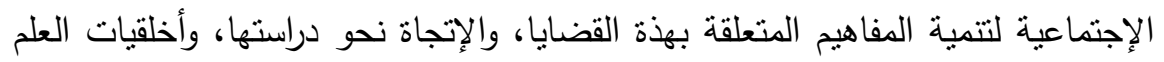

لمعلمي العلوم أثناء الخدمة. مجلة التربية العلمية. الجمعية المصرية للتربية العلمية.

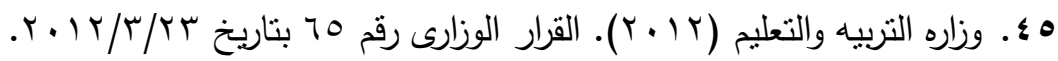

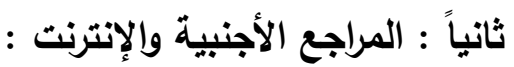

46. Allan, J\& Street, M (2007). The Quest for Deeper Learning:

AnInvestigation into the Impact of a Knowledge-Pooling WebQuest in Primary Initial Teacher Training. British Journal of EducationalTechnology, v38, n6, pp 1102-1112.

47. Balmush. N; Dumbravianu.R. (2005). Virtual laboratory in optics. Third International Conference on Multimedia and Information \& Communication Technologies in Education june 7-10th, 2005.

48. Cathy‘B (2010). Technology \&literacy in early childhood education al setting rjournal of early childhood‘vol 10 no3 247-270،Sheffield Hallam University.

49. Chandler( 2002.) «les idées essentielles des auteurs les plus cités « édition maxima, paris 2002p.

50. Coffman, Teresa (2004). Online Professional development Transferring Skills learned to the classroom, CAPELLA University.

51. C. Kennedy( 2002). "Les idées essentielles des autres les plus cités », édition Maxime, Paris.

52. Dillon, s, (2007). Virtual Science Labs. New York Times Upfronrt, Feb, 193, 10, Research Library, 26.

53. Daniel, y, Wang, y (2008). Multi-criteria evaluation of the web - based E- learning system: A methodology based-on learner satisfaction and its

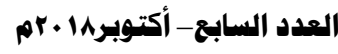




\section{المجلة العلمية لكلية رياض الاطفال - جامعة اسيوط}

Applications, computers \& education volume 50, ISSUES, April 2008 pages 894-905.

54. Halat, E (2008) . The Effects of Designing Webquests on the Motivation of Pre-Service Elementary School Teachers International. Journal of Mathematical Education in Science and Technology, v39, n6, pp793802.

55. Hawsawi, A. (2002). Teacher's perceptions of computers technology competencies working with students with mild cognitive delay. Unpublished doctoral dissertation, University of Idaho, Moscow, ID. USA.

56. Heiman, M. T, jus. \& Nelson, K, E. (2002). Interaction patterns between children and their teachers when using a pacific multimedia and communication strategy: observation- from children with autism

57. Igor Ansoff,( 2007).Strategic Management Classic Edition [H. Igor Ansoff, G.I. Nakamura] on Amazon.com. First edition (May 11, 2007); Language: English; ISBN-10: 0230525482.

58. Ikpeze, C\& Boyd, F (2007) . Web-Based Inquiry Learning: Facilitating Thoughtful Literacy with WebQuests.Reading Teacher, v60 n7 pp644654.

59. Jensen, N.; Voigt, G.; Nejdl, W. \& Olbrich, S. (2004) "Development of a Virtual Laboratory System for Science Education" Interactive Multimedia Electronic Journal of Computer-: Enhanced Learning Retrived on: 11/2007 Martinez-Jimenez, P.; Pontes-Pedrajas, A.; Polo, J.; Climent-Bellido.

60. King, k (2003).The WebQuest as a Means of Enhancing Computer Efficacy Web site:www.ebscohost.com/ehost/detail?pp1-17
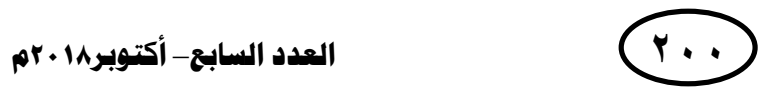
61. Mendez Daniel (2014). The effects of games format computer assisted instruction academic achievement in language arts, Galifoon State University, Master thesis.

62. Roger, L, Aveyard. (2001). A visual attention study for developing learning cues for individual with mental retardation. Psychological and Cultural Studies, Lincoln, Nebrasca.

63. Stephen J. Schmidt (2003). Active and cooperative Learning Using Web- Based Simulations, Journal of Economic Education, vol.34.no2, Spring 2003, pp.151-

64. Waas, T., Hugé, J., Ceulemans, K., Lambrechts, W., Vandenabeele, J., Lozano, R., Wright, T. (2012). Sustainable Higher EducationUnderstanding and Moving Forward. FlemishGovernmentEnvironment, Brussels :Nature and Energy Department,

65. https://discoveryeducation.ekb.eg/about-ekb/

66. https://sdl.edu.sa/SDLPortal/ar/post.aspx? $\mathrm{p}=9142$

67. http://sis.gov.eg/section/2383/7179?lang=ar

68. http://qalubiaedu.org/

69. http://www.khayma.com/educationtechnology/Study3.htm

70. http://www.alukah.net/social/0/81066/\#ixzz5NgB5SrxV

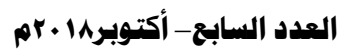

